\title{
Eszter Lilla SERES * \\ The question of compliance with the polluter-pays principle and State aid rules within the European Emission Trading Scheme **
}

\section{Introduction}

In the last decades, the topic on climate change has become a top issue that is considered on both international and European level. Thus aligning with the parallel international development tendencies had the European Union taken up the impetus in the advancement of this specific area.

With the gradual expansion of the European Community policies the question of environmental concerns being considered under competition law as well with specific regard to State aid rules. This question became quite relevant with the EU accessing the Kyoto Protocol, undertaking the obligation to reduce greenhouse gas emission by the commitment period of 2008-2012. The accession has led to the adoption of Community measures establishing a common European approach towards greenhouse gas emission, yet leaving enough space for the questioning of compatibility of EU legislation with the polluter-pays principle.

This essay aims at pointing out the core issues of the European Emission Trading Scheme with regard to the polluter-pays principle. The issue can be addressed through the analysis of the concept of State aid and their environmental implications. The main aim is to come to be able to come to a conclusion whether it is possible to strike a balance between environmental considerations and competition rules or whether there would be always a shift between the two approaches, precluding the possibility to address these issues together.

\section{The importance of the polluter-pays principle}

The polluter-pays principle has a history rooting back to its formation as an economic, rather than an environmental principle under the aegis of Organisation for Economic Co-operation and Development (OECD) in 1972, according to which "the polluter should bear the expenses of carrying out the measures decided by public authorities to ensure that the environment is in an acceptable state. In other words, the cost of these measures should be reflected in the cost of goods and services which cause pollution in production and or consumption. Such measures should not be accompanied by subsidies that would create significant distortions in international trade and investment."'

\footnotetext{
* dr. jur., legal officer, Department of Competition Law, Consumer Protection and Intellectual Property Rights, Ministry of Justice, e-mail: eszter.seres.92@gmail.com

** The opinions expressed in this article are the author's own and do not reflect the view of the Ministry of Justice; responsibility for the information and views expressed herein lies entirely with the author.
} 
The principle refers to the scarcity of environmental resources that nature has to be taken into account in the cost of production, so it can be correctly reflected in the market. ${ }^{2}$ These failures can only be corrected by public measures capable of properly reflecting environmental deterioration in the prices of goods and services, enabling the allocation of costs of pollution prevention and control measures introduced by governments for polluting undertakings encouraging the rational use of environmental resources' and helps to 'avoid distortions in international trade and investment.'3

These State measures can have differentiated importance, especially in relation to environmental protection: they can be used to eliminate an external cost or can be provided by the State for other environmental reasons. ${ }^{4}$ Under the category of capturing an external impact, such subsidy internalizes an externality. ${ }^{5}$ In this sense, these externalities have negative nature that had been identified by economists as market failures generally leading to public good or bad. ${ }^{6}$ For instance, pollution by a firm in the course of production is considered a negative externality. ${ }^{7}$ This serves as a clear indication of the fact that firms during the course of production, in which the input process utilises the environmental resources. ${ }^{8}$ Due to the fact that certain amount of environmental degradation caused by a firm does not entail any cost for it, only has negative effect at societal level, the degradation - from the side of the market - does not necessarily become apparent at the time of the pollution. ${ }^{9}$

${ }^{1}$ OECD: Recommendation of the Council on Guiding Principles concerning International Economic Aspects of Environmental Policies, C (72)128, 1972, point 4., in: http://acts.oecd.org/Instruments/ShowInstrumentView.aspx?InstrumentID=4\&InstrumentPI $\mathrm{D}=255 \&$ Lang $=$ en $\&$ Book $=(11.10 .2016)$

2 OECD 1972, para. 2.; See further: Csák Csilla: Thoughts about the problems of the enforcement of the polluter pays principle, European Integration Studies, 2011/1, 27-40.

${ }_{3}^{3}$ Philippe Sands: Principles of International Environmental Law, Cambridge, Cambridge University Press, 2003, 281., https://doi.org/10.1017/CBO9780511813511; Bándi Gyula: A szennyezô fizet elv és a környezetre veszélyes tevékenységgel okozott károkra vonatkozó felelősségi szabályok európai trendjei, in: Margitán Éva et al (edit.): Nyugat-európai hatások a magyar jogrendszer fejlódésében, Budapest, ELTE-ÁJK, 1994, 136-162.

${ }^{4}$ Hyun-Jing Kim: Subsidy, Polluter Pays Principle and Financial Assistance; Journal of World Trade Law, 2000/34., 119.; Nagy Zoltán: Környezeti adózás szabályozása a környezetpolitika rendszerében, Miskolc, Miskolci Egyetem, 2013, 44-77.

${ }^{5}$ Hyun-Jing Kim 2000, 120-121.

${ }^{6}$ Hans Vedder: Competition Law and Environmental Protection in Europe; Towards Sustainability?, Groningen Europa Law Publishing, 2003, 15.; Nagy Zoltán: The Instruments of the Environmental Policy's Economic Regulation with a Particular Regard to the Hungarian System, Lex Et Scientia, 2014/1, 77-88.

${ }^{7}$ Moritz Lorenz: An Introduction to EU Competition Law, Cambridge, Cambridge University Press, 2013, 23-24., https://doi.org/10.1017/CBO9781139087452; Bándi Gyula: Környezetjog, Budapest, Szent István Társulat, 2011, 56-58.

8 OECD: Economic Instruments for the Environmental Protection, Working Paper No. 92, 1989, In: http://www.oecd.org/dev/1919252.pdf (20.10.2016) 5.

9 Vedder 2003, 15.; See further: Bobvos Pál - Csák Csilla - Horváth Szilvia - Olajos István Prugberger Tamás: A szennyezô fizet elv megjelenése a mezőgazdaságban, Journal of Agricultural and Environmental Law, 2006/1, 29-55. 
At EU-level, the polluter-pays principle itself has been defined under Article 191 (2) of the Treaty on the Functioning of the European Union (TFEU), as the environmental policy of the Union is, inter alia, based on the polluter-pays principle.

\section{The applicable rules concerning State aid measures}

\subsection{Qualification of the measure as State aid}

The general aim of providing State aid in the field of environmental protection is to ensure that by the application of such measures the level of environmental protection will be higher than it would occur without the aid. ${ }^{10}$ Without such subsidies, the market would fail to efficiently allocate resources, enabling the occurrence of negative externalities.

In general, unless otherwise provided, Article 107 (1) TFEU lays down the rule for the prohibition of granting State aid. ${ }^{11}$ A State measure involving financial gains for certain undertakings that fulfils certain criteria will be considered as a State aid. These criteria are the following ones: the transfer of state resources, the advantage provided for an undertaking, selectivity, the distortion to competition and effect on trade between Member States. ${ }^{12}$ As the case-law of the European Court of Justice does not provide an exact definition on State aid, rather describe measures and decisions of "Member States in pursuit of their own economic and social objectives, give, by unilateral and autonomous decisions, undertakings or other persons resources or procure for them advantages intended to encourage the attainment of the economic or social objectives sought."13

Firstly, the measure shall constitute a transfer of state resources, meaning that "only advantages granted directly or indirectly through State resources are to be considered an aid." 14 The distinction made in that provision between aid granted by a Member State and aid granted through State resources does not signify that all advantages granted by a State, - whether financed through State resources or not - constitute a State aid but is intended merely to bring within that definition any advantages which are granted

\footnotetext{
${ }^{10}$ Conor Quingly: European State Aid Law and Policy, Oxford, Hart Publishing, 2009, 271.; Olajos István: A vidékefejlesztési jog kialakulása és története, Miskolc, Novotni Kiadó, 125-126.; Guidelines on State aid for environmental protection and energy 2014-2020, OJ C 200, 2014, para. 30., in: http:// eur-lex.europa.eu/legal-content/EN/TXT/?uri=CELEX\%3A52014XC0628(01) (19.10.2016)

11 Article 107(1) TFEU: „Save as otherwise provided in the Treaties, any aid granted by a Member State or through State resources in any form whatsoever which distorts or threatens to distort competition by favouring certain undertakings or the production of certain goods shall, in so far as it affects trade between Member States, be incompatible with the internal market."

${ }^{12}$ Legih Hancher - Tom Ottervanger - Piet Jan Slot: EC State Aids, London, Sweet \& Mawell, 2006, 500 .

13 Case C-61/79 Amministrazione delle Finanze Stato v Devankit Italiana [1980] ECR 198001205, para. 31 .

${ }^{14}$ Case C-379/98 PreussenElektra AG v Schhleswag AG [2001] ECR I-02099, para. 58.
} 
Eszter Lilla Seres

The question of compliance with the polluter-pays principle and State aid rules within the European Emission Trading Scheme
Journal of Agricultural and

Environmental Law

$21 / 2016$

"directly by the State and those granted by a public or private body designated or established by the State. $" 15$

Additionally, the notion of State aid can encompass not only positive benefits, such as subsidies, loans or direct investment in the capital of enterprises, but also interventions that mitigate the charges which are normally included in the budget of an undertaking. ${ }^{16}$ Secondly, the aid has to be imputable to the State. ${ }^{17}$ In this manner, when the measure and granting is determined by a body that is subjected to the control and the instructions of the public authorities, it is attributable to the Member State concerned by possibly forgoing the profit which it normally could realize. ${ }^{18}$ Thirdly, the grant of funds must be subject to approval by the public authorities. ${ }^{19}$

For the second requirement, that the advantage must be provided for an undertaking, Article 107 (1) TFEU covers both private and public undertakings. ${ }^{20}$ Under EU competition law, any person or organisation pursuing an economic activity is considered an undertaking. ${ }^{21}$ Thus regardless of the legal status of the entity and the way in which it is financed, ${ }^{22}$ the main emphasis is put onto the examination of whether the undertaking offers goods or services on a market, ${ }^{23}$ without the necessity of generating profit. ${ }^{24}$

The third criterion for a measure to qualify as a State aid is selectivity. Speaking in general terms, Member States cannot be compelled to refrain from the introduction of measures belonging to the area of general economic policy, ${ }^{25}$ meaning that the criterion of selectivity will be only met if under a "particular statutory scheme a State measure favours certain undertakings or the production of certain goods over others which are in a legal and factual situation that is comparable in the light of the objective pursued by the measure in question."'n

\footnotetext{
${ }^{15}$ Case C-379/98 PreussenElektra, para. 58.

${ }^{16}$ Case C-126/01 Ministère de l'Économie, des Finances et de l'Industrie v GEMO SA. [2003] ECR I-13769, para. 28.

${ }_{17}$ Case C-482/99 France v Commission (Stardust Marine) [2002] ECR I-04397, para. 68.

18 Case C-67/85 Kwekerij Gebroeders Van der Kooy BV and Others v Commission of the European Communities, [1988] Reports of Cases 198800219 para. 220.

${ }^{19}$ Vedder 2003, 285.

${ }^{20}$ Case C-78/76, Steinike \& Weinlig v Federal Republic of Germany [1977] Reports of Cases 197700595 para. 18.

${ }^{21}$ Várnay Ernő - Papp Mónika: Az Európai Unió joga, Budapest, Complex Kiadó, 2013, 713.

22 Case C-41/90 Klaus Höfner and Fritz Elser v Macrotron GmbH. [1991] Reports of Cases 1991 I-01979 para. 21.

${ }^{23}$ Várnay - Papp 2013, 713-714.

${ }^{24}$ European Commission: Commission notice on the notion of State aid as referred to in Article 107 (1) of the Treaty on the Functioning of the European Union, C 262/01, 2016, para. 9., in http://eur-lex.europa.eu/legal content/EN/TXT/PDF/?uri=CELEX:52016XC0719(05)\&from $=\mathrm{EN}(22.10 .2016)$

${ }^{25}$ Várnay - Papp 2013, 1004.

${ }^{26}$ Case C-409/00 Kingdom of Spain v Commission of the European Communities. [2003] ECR I-01487 para. 47.
} 
When the body granting financial assistance enjoys a degree of latitude, enabling it to choose the beneficiaries or the conditions under which the financial assistance is provided, that assistance cannot be considered to be a general economic measure in nature, ${ }^{27}$ leading to the conclusion that discretion on the part of the aid granting authorities can be seen as an indicator of selectivity. ${ }^{28}$

Finally, the fourth criterion is the effect on trade between the Member States, namely that the State aid must be capable of distorting competition and affecting trade between Member States.

\subsection{Compatibility of State aid with the Internal Market}

An environmental measure qualified as State aid may still be legal if it is held to be compatible with the Internal Market under Article 107 (3)(c) TFEU. Under Article 107 (3) TFEU the Commission has discretionary power to consider an aid compatible with the internal market rules. This discretionary power of the Commission is now delimited by the Commission Regulation on General Block Exemption Regulation (GBER), ${ }^{29}$ under which State aid measures aiming at the protection of the environment has gained emphasis with the parallel underlining of the polluter-pays principle.

As environmental protection is one of the main horizontal objectives in State aid regulation, ${ }^{30}$ the Commission has issued the Guidelines on State aid for environmental protection that is now available for the period of 2014-2020 (the Guidelines). In general, the aim of the Guidelines is to protect the environment in such manner to support any action is designed to remedy or to prevent damage to the environment or natural resources and to the encouragement of the uses of these resources. $^{31}$ It provides a degree of transparency for Member States and for undertakings to be able to foretell the criteria they will have to meet and that the Commission will apply in the course of assessment on compatibility with the internal market rules. ${ }^{32}$ Yet it does not generally assume the compatibility of every aid that is covered by it, only providing a presumption for compatibility in cases of meeting certain criteria set out in it.

The Guidelines emphasize the need for positive or incentive effect of an environmental aid to be considered compatible. This incentive effect means that the aid has to induce the beneficiary to change its behaviour to increase the level of environmental protection that would have not been undertaken without the aid. ${ }^{33}$

${ }^{27}$ Case C-256/97 Déménagements-Manutentuin Transport SA [1999] ECR I-03913 para. 27.

${ }^{28}$ Vedder 2003, 293.

29 Commission Regulation No. 651/2014 of 17 June 2014 declaring certain categories of aid compatible with the internal market in application of Articles 107 and 108 of the Treaty

${ }^{30}$ Várnay - Papp 2013, 1014.

${ }^{31}$ Hancher - Ottervanger - Slot 2006, 508.

32 Volker Zuleger: Compatibility of State Aid pursuant to Article 87 (3) EC, In: Martin Heidenhain (edit.): European State Aid Law; Munich, Beck, Hart and Namos Publishing, 2010, 270.

332014 Guidelines, para. 49. 
This effect is required to be present in all aid measures, leading to an extra level of protection in relation to the given situation. ${ }^{34}$ An aid cannot be considered necessary solely because the level of environmental protection is increased. ${ }^{35}$ Measures under which the negative effects manifestly outweigh the positive effect of the aid cannot be deemed compatible with the internal market. ${ }^{36}$ On the basis of the negative and positive effects, the Commission will balance the effects and determine whether the resulting distortions adversely affect trading conditions to an extent contrary to the common interest. ${ }^{37}$ If the expected negative effects outweigh the positive effects, the environmental aid cannot be executed whereas in the case of positive effects prevailing, the Member States will be permitted to provide the aid for the undertakings.

\section{The European Emission Trading Scheme (ETS)}

From the point of view of international environmental law, with the 1997 adoption of the Kyoto Protocol to the UN Framework Convention on Climate Change, the quantitative restrictions on emissions from industrialised economies has been established. ${ }^{38}$ The Protocol provides a global market ${ }^{39}$ for trading in emission permits between industrialised countries.

In Article 17 the Kyoto Protocol sets out the basics of emission trading. Article 3 of the Protocol aims the reduction of overall emissions by the contracting parties of greenhouse gases by at least 5\% below their 1990 levels for the commitment period 2008 to 2012. If the Parties have not met their commitments set out in Annex B, then they are able to trade units in the form of assigned amount units, certified emission reductions, emission reduction units and removal units. ${ }^{40}$

In 2001 the Commission has issued a Green Paper on greenhouse gas emissions trading within the European Union, ${ }^{41}$ which has established a conceptual framework and basic ideas for the European Emission Trading Scheme.

\footnotetext{
${ }^{34}$ Phedon Nicolaides - Maria Kleis: A Critical Analysis of Environmental Tax Reduction and Generation Adequacy Provisions in the EEAG 2014-2020, European State Aid Law Quarterly, 2014/14, 639-640.

${ }^{35}$ Quingley 2009, 291.

362014 Guidelines, para. 94.

${ }^{37}$ Quingley 2009, 293.

38 Patricia Birnie - Alan Boyle - Catherine Redgwell: International Law and the Environment, Oxford, Oxford University Press, 2009, 360-361.

39 OECD: Emission Permits and Competition, DAF/COMP(2010)35, 2011, in: http://www.oecd.org/competition/sectors/48204882.pdf, (10.11.2016) 32.; See further: Fodor László: A kibocsátási egységek kereskedelme: Európajogi alapok - a német és a magyar nemzeti szabályozás 2004-2012 között, Journal of Agricultural and Environmental Law, 2013/14, 3-52.

40 Birnie - Boyle - Redgwell 2009, 367.

${ }^{41}$ European Commission: Green Paper on greenhouse gas emissions trading within the European Union, COM/2000/0087, in: http://eur-lex.europa.eu/legal-content/EN/TXT/?uri=celex\%3A52000 DC0087 (10.11.2016) point 7.1.
} 
Even by that time, the Commission had already taken the view that some of the measures adopted by Member States in order to comply with the Kyoto Protocol could constitute a State aid, yet it took the view it was "too early to lay down the conditions for authorising any such aid." 42

In the Paper, the Commission outlined how crucial was the establishment of a scheme that could place equitable burden on every sector or actor within the ETS compared to actors outside of it. The Commission has emphasised two different market-based instruments through what the scheme should be approached: auctioning or grandfathering of allowances, in other words, allocation free of charge. 43 Auctioning is basically in line with the polluter-pays principle, as the revenues from the auctioning can be utilised in many possible ways in order to decrease environmental harm and enhance the level of protection. On the other hand, a different approach called benchmarking was considered, as grandfathering could only provide a solution on the basis of a historical emission data that would lead to rewarding the largest emitters and not for companies who already undertook measures for the reduction of environmental harm. Benchmarking provides a basis to set up performance standards in relation to a specific installation that during the course of production harms the environment. ${ }^{44}$

Finally, the insights provided by the Green Paper have led to the adoption of the 2003/97/EC Directive establishing the European Emission Trading Scheme (ETS). 45 The main aim of the establishment of the ETS is to "promote reductions of greenhouse gas emissions in a cost-effective and economically efficient manner." ${ }^{46}$

\footnotetext{
${ }^{42}$ European Commission: European Emission Trading Scheme Handbook, 71.

${ }^{43}$ In the Green Paper, grandfathering had been defined as strictly not being ,related to the notion of the allocation free of charge of a realisable asset, but rather to a bistorical right to do something, such as vote, that can be transmitted to descendants or retained by a legal entity during its continued existence, but which is not transferable beyond those pre-determined limits.”; See further: Fodor László: A kibocsátási egység - új típusú vagyoni értékủ jog a klímavédelem szolgálatában, Collectio Iuridica Universitatis Debreceniensis, 2008/7, 161-200.

${ }^{44}$ European Commission: Green Paper 2000, point 7.2.2.

45 Directive 2003/87/EC of the European Parliament and of the Council of 13 October 2003 establishing a scheme for greenhouse gas emission allowance trading within the Community and amending Council Directive 96/61/EC; Concerning the European Emission-Trading Scheme see further: Az uniós emisszió-kereskedelmi rendszerről lásd: Horváth Szilvia: A kibocsátási jogok kereskedelmének nemzetközi háttere, közösségi szabályozásának alakulása, PhD-értekezés, SZTE, 2007; and Horváth Szilvia: Az Európai Közösség éghajlatváltozás elleni politikájának kezdeteiről, Journal of Agricultural and Environmental Law, 2007/2, 20-40.

${ }^{46}$ EU ETS Directive, Article 1.
} 
This scheme has established a so-called cap-and-trade system, or absolute regime, ${ }^{47}$ that provides an overall greenhouse gas emission capping for all participants of the regime, with a fixed upper limit. ${ }^{48}$ The system provides a possibility for undertakings carrying out a polluting activity to buy emission allowances from other undertakings that can abate at lower costs. ${ }^{49}$

The first phase of the ETS took place from 2005-2007, while the second phase of 2008-2012,50 each Member State could decide upon the total quantity of allowances it would allocate. ${ }^{51}$ Under Phase 1 and 2 , the emission permits were granted free to the emitters, as it was presumed that it would substantially reduce the costs for installations, while - questionably - keeping the economic incentives to reduce emissions. ${ }^{52}$ In the first period, the scheme provided the possibility for Member States to auction their allowances up to $5 \%$, while in Phase 2, this limit had been increased to $10 \%$ while allowances had to be supported by an Assigned Amount Unit as there was an inherent State aid potential by the free or below market price allocation of allowances under the EU ETS. 53

One of the striking specialties of the Directive was that it only provided restriction on the upper limit of the national emission cap in Annex III that had be consistent with the commitments under the Kyoto Protocol. Secondly, under Article 10 , in the first phase, $95 \%$ of the allowances, while for the second phase $90 \%$ had to be allocated free of charge - through grandfathering. Although in the Green Paper the Commission had argued that auctioning would be the more favourable approach, at the outcome, clearly the provision of a larger leeway for Member States had prevailed. Furthermore, the Directive itself does not provide any guidance in connection to State aid provisions, only states that, under Annex III, "national allocation plans shall not discriminate between companies or sectors in such a way as to unduly favour certain undertakings or activities in accordance with the requirements of Articles 87 and 88 of the Treaty."

As the polluter-pays principle formed an integral part of the EU environmental policy, it is quite questionable that in Phase 1 and 2 the allocation free of charge could be considered as an approach consistent with environmental concerns. Strictly interpreted, through the granting of free allowances, the Member States undertook to renounce incomes that could be invested into the levelling of environmental protection.

\footnotetext{
47 Suzanne Kingston: The role of Environmental Protection in EC Competition Law and Policy, PhD thesis, 2009 in: https://openaccess.leidenuniv.nl/bitstream/handle/1887/13497/Suzanne+Kingston $+\mathrm{PhD}+\mathrm{Th}$ esis.pdf?sequence $=1$ (11.11.2016) 50.; Nagy Zoltán: Az emisszió-kereskedelmi rendszerek szerepe a környezetpolitikában, in: Raisz Anikó (edit.): A nemzetközi környezetjog aktuális kibivásai, Miskolc, Miskolci Egyetem, 2012, 118-128.

${ }^{48}$ European Commission: European Emission Trading Scheme Handbook. 16.

49 OECD: Emission Trading Systems, in: http://www.oecd.org/env/toolsevaluation/emissiontradingsystems.htm (10.11.2016)

${ }^{50}$ Fodor László: A kibocsátási egységek kereskedelmi rendszerének bevezetése Magyarországon, Publicationes Universitatis Miskolciensis Series Juridica et Politica, 2007/25/1, 289-316.

${ }^{51}$ ETS Directive Article 11.

52 OECD 2011, 173.

${ }^{53}$ Kingston 2009, 255.
} 
Eszter Lilla Seres

The question of compliance with the polluter-pays principle and State aid rules within the European Emission Trading Scheme
Journal of Agricultural and

Environmental Law

$21 / 2016$

Yet from the other point of view, it can be argued that only the subsequent $5 \%$ and 10\% accorded within Phase 1 and 2 could be seen as the bypassing of the polluter-pays principle, as Member States were granted a small but existing latitude concerning these percentages. Furthermore, as Annex III of the Directive had only provided a general reference to the State aid rules under the Treaty, the question on what national measures could amount to State aid under the ETS was left open. Theoretically, the scheme was inconsistent with State aid rules as it provided tradable emission permits free of charge, while having recourse to auctioning, these tradable permits could have become part of the State revenues. Clearly, under ETS, the Member States forfeited these revenues and undertakings that had previously abated their level of emission could capitalise the amount of allowances in excess of their usage.

Considering the notion of State aid, Phase 1 and 2 of the EU ETS can be assessed in the following points. Firstly, as is has previously been established, the aid must be granted by a Member State or at least indirectly through State resources, by a public body or a private body established by the State. According to the analyzation of LORENZ, the representative opinion at the time of the establishment of the ETS were that the regime precludes the existence of an aid, "as the benefits form the tradability of the allowances stems from the trade between private parties. "54 The other group of literature counter argued that the potential revenues that were inherent in the emission allowances are tantamount to the requisite of granting through state resources. The second criteria is the conferring an economic advantage on undertakings. As the undertakings who were participants of the affected industrial sectors could benefit from the ETS cap-and-trade system without having to buy the allowances, the allocation had provided an advantage that could be fully utilised or later sold to other participants or new entrants. Thirdly, the question of selectivity has to be examined from the side of the sectors covered and the participants of the scheme. The system cannot be regarded as being selective on the basis that it covers only certain sectors, yet the Commission in some cases considered that the coverage of only certain industry sectors and companies amounts to selectivity. ${ }^{55}$ The issue of selectivity can be found in the core of the ETS as well. As Member States had to allocate and auction the allowances at the beginning of the phases, the late entrants had to purchase the allowance they would need through the market. ${ }^{56}$ The following issue is the distortion of competition that the Commission itself had recognised in emission trading schemes before the ETS Directive had entered into force. ${ }^{57}$ Furthermore, the distortion of competition can appear in relation to an energy efficient undertaking that had undertaken actions to reduce its emission prior to participation in such scheme and national allocation plans does not take such considerations into account. ${ }^{58}$

\footnotetext{
54 Moritz Lorenz: Emission Trading - State Aid Dimension, European State Aid Law Quarterly, 2004/3, 401.

${ }_{55}$ Lorenz 2004, 402.

56 2014-2020 Guidelines, para. 235.

${ }^{57}$ Commission Decision of 28.11.2001, Case N 416/2001 - United Kingdom, 9.

${ }^{58}$ Lorenz 2004, 402.
} 
Eszter Lilla Seres

The question of compliance with the polluter-pays principle and State aid rules within the European Emission Trading Scheme
Journal of Agricultural and

Environmental Law

$21 / 2016$

\section{The Dutch $\mathrm{NO}_{\mathrm{x}}$ Emission Trading Scheme}

The regime had been established previously to the adoption of the ETS Directive. The Dutch regime was created on the basis of the Directive 2001/81/EC on national emission ceilings for certain atmospheric pollutants. Under the Directive, the Dutch national emission ceiling was set at 260 kilotons by 2010.59 The authorities considered that emission permit requirements and legislation on the emission limits were insufficient instrument in meeting the target for 2010.60 So the introduction of a new scheme deemed to be crucial. The system to be established was mandatory and every undertaking must have complied with the scheme by abating $\mathrm{NO}_{\mathrm{x}}$ in their facilities or by purchasing emission reduction allowances that were or would be achieved elsewhere, or by a combination of both. ${ }^{61}$ Under the scheme parallel to the compulsory compliance, trading was optional, where the facilities could decide whether and to what extent do they wish to exchange emission reductions for the given year or for the future year. The scheme was called a dynamic cap system. ${ }^{62}$ As the upper cap was not limited, but was dynamic with the possibility of gradual growth. The Dutch authorities have set an upper ceiling for selling may not exceed the maximum reductions that an undertaking can make given the emission standard. ${ }^{63}$

The Commission during the course of its procedure noted that with the authorities having an option to sell or auction emission permits, it has led to the establishment of a scheme in which the permits constitute State resources within the meaning of Article 87 (1) of the EC Treaty. ${ }^{64}$ Furthermore, as the scheme was only favourable for the largest 250 undertakings, constituting a specific group that was active participation in trade between Member States, the scheme strengthens their position, leading to the change of market conditions for their competitors. Although the conditions for the measure to be caught under Article 87 (1) had been clearly established, the Commission had examined whether it can be saved under Article 87 (3)(c). As the trading scheme was an additional effort before the adoption of Community rules that rewarded undertaking which went beyond the existing standards, achieving environmental benefit, the Commission considered the measure compatible with the common market, saved under Article 87 (3)(c).

59 Commission Decision C(2003) of 24 June 2003 on State Aid N 35/2003 - Ducth $\mathrm{NO}_{\mathrm{x}}$ Emission Trading Scheme, 1.

${ }^{60}$ Hancher - Ottervanger - Slot: 2006, 544.

${ }^{61}$ Commission Decision N 35/2003 - Ducth $\mathrm{NO}_{\mathrm{x}}$ Emission Trading Scheme, 2.

${ }^{62}$ Commission Decision N 35/2003 - Ducth $\mathrm{NO}_{\mathrm{x}}$ Emission Trading Scheme, 5.

${ }^{63}$ Commission Decision N 35/2003 - Ducth $\mathrm{NO}_{\mathrm{x}}$ Emission Trading Scheme, 7.

${ }^{64}$ Commission Decision N 35/2003 - Ducth $\mathrm{NO}_{\mathrm{x}}$ Emission Trading Scheme, 9. 
The decision of the Commission was subjected to criticism as it did not take into account certain circumstances, such as that large industrial facilities were subjected to additional emission requirements compared to other facilities and that the value of the permits were as much dependent on the effort of the participating facilities as of the government's permission to trade them. ${ }^{65}$ Moreover, the other argument criticising the Commission's approach is that there were no existing allowances until there's an undertaking acting under the scheme that would be producing so efficiently to create allowances. ${ }^{66}$

After the Commission's decision the case was tried before the Court of First Instance, coming to the conclusion that the $\mathrm{NO}_{\mathrm{x}}$ trading scheme constituted an advantage granted to the undertakings concerned through State resources. This line of argument was based on the circumstances that the scheme authorised undertakings subject to those standards to trade the emission allowances between themselves up to the limit applicable to each of them, thus due to the tradability of the allowances, the scheme conferred market value onto them. ${ }^{67}$ It is therefore the tradability of the allowances provided by the measure that constitutes an advantage for the enterprises. ${ }^{68}$ Furthermore, the CFI had examined the question of selectivity as well, coming to the conclusion that the scheme was based on objective considerations and that the measure in question aimed at the undertakings being the largest polluters setting out an objective criterion in conformity with the goal of the measure, namely, the protection of the environment. ${ }^{69}$ With regard to the objective pursued and the specific obligations imposed on large industrial facilities by the measure in question, the CFI held that the legal and factual situation of the undertakings subject to that $\mathrm{NO}_{\mathrm{x}}$ emission ceiling cannot be regarded comparable with undertakings to which that ceiling does not apply. ${ }^{70}$ The mere possibility to restrict the measure concerned to 250 undertakings was not enough to establish the existence of a selective measure. ${ }^{71}$ Thus without the selectivity criterion being fulfilled, the measure could not be seen as State aid under Article 87 (1).

\footnotetext{
65 Piet Jan Slot: $\mathrm{NO}_{\mathrm{x}}$ Emission Trading Rights: A Government Gift or Value Created by Undertakings?; European State Aid Law Quarterly, 2013/12, 62.

${ }^{66}$ Slot 2013, 67.

${ }^{67}$ Case T-233/04, Kingdom of the Netherlands v Commission of the European Communities [2008] ECR II-00591 para. 70.

${ }^{68}$ Case T-233/04, Kingdom of the Netherlands v Commission of the European Communities [2008] ECR II-00591 para. 74.

${ }^{69}$ Case T-233/04, Kingdom of the Netherlands v Commission of the European Communities [2008] ECR II-00591 para. 88.

${ }^{70}$ Case T-233/04, Kingdom of the Netherlands v Commission of the European Communities [2008] ECR II-00591 para. 90.

${ }^{71}$ Case T-233/04, Kingdom of the Netherlands v Commission of the European Communities [2008] ECR II-00591 para. 95.
} 
After the CFI's judgement, the case on appeal was tried before the Court. Regarding selectivity, the Court had established that the concept of aid "does not encompass measures creating different treatment of undertakings in relation to charges where that difference is attributable to the nature and general scheme of the system of charges in question" "The ECJ had analysed whether the Netherlands could prove that the measure was capable to avoid the classification as being selective for the purposes of Article 87 (1) EC Treaty, it came to the conclusion that neither the nature, nor the general scheme of that legislation was capable to justify such differentiation. ${ }^{73}$

Concerning the question whether the characteristic of the Dutch scheme was of an advantage granted through State resources, the Court provided the following interpretation. As the tradability of emission allowances is dependent on the fact that the State authorises the sale of those allowances and that the State allows those undertakings emitting a surplus to acquire from other undertakings the missing emission allowances, this enables the creation of a market for the allowances. ${ }^{74}$

\section{The revision of the ETS scheme}

As for the third phase, the ETS went through significant developments. The $2009 / 29 /$ EC Directive $^{75}$ even aims at the unfolding of a larger-scale of potential of the ETS - partially learning from the mistakes of the first two phases. The Directive has introduced a new target for the reduction of greenhouse gas emissions of $20 \%$ decrease compared to the level of the 1990 emissions, with a view to shift to full auctioning by $2027 .^{76}$ In order to achieve this aim, the quantity of allowances shall be decreased annually, equally to $1,74 \%$ of the allowances. ${ }^{77}$ The scheme had been extended to other forms of facilities, providing a larger scope of application to industrial activities. ${ }^{78}$

The New Directive had already addressed the issue of carbon leakage as well, ${ }^{79}$ namely, the phenomenon under which the emission reduction initiatives in one country may lead to the increase of emissions in other countries, as undertakings from a country applying a more stringent approach in emission reductions might just outsource its producing activity to countries where the emission regulation is not that demanding, leading to a sector-specific leakage that can be in the range from 0 to $100 \% .80$

\footnotetext{
${ }^{72}$ Case C-279/08 P European Commission v Kingdom of the Netherlands [2011] ECR I-07671 para.62.

${ }^{73}$ Case C-279/08 P European Commission v Kingdom of the Netherlands [2011] ECR I-07671 paras. $76-78$.

${ }^{74}$ Case C-279/08 P European Commission v Kingdom of the Netherlands [2011] ECR I-07671 para. 88 .

75 Directive 2009/29/EC of the European Parliament and of the Council of 23 April 2009 amending Directive 2003/87/EC so as to improve and extend the greenhouse gas emission allowance trading scheme of the Community

${ }^{76}$ Directive 2009/29/EC, Preamble, point 5.

77 Directive 2009/29/EC, Preamble, point 13.

${ }_{78}$ Directive 2009/29/EC, Preamble, point 10.

${ }^{79}$ Directive 2009/29/EC, Preamble, point 26.

${ }^{80}$ OECD 2011, p. 10.
} 
In this relation, the New Directive had considered the possibility for Member States to provide for the temporary compensation for installations that face "a significant risk of carbon leakage for costs related to greenhouse gas emissions passed on in electricity prices," given that granted support has to be necessary and proportionate. ${ }^{81}$

Article 10 of the New Directive shows a swift change from the grandfathering approach towards the auctioning of allowances. Furthermore, it wishes to provide a more compatible approach with the polluter-pays principle, as $50 \%$ of revenues generated from the auction of allowances should be used for different environmental protection aims, such as investments into renewable energies, avoidance of deforestation and environmentally safe capture and storage of carbon-dioxide. ${ }^{82}$

In order to achieve full allocation through auctioning until 2027, a transitional period is still necessary. Under this period, a Community-wide ex-ante benchmarking has to be established that is for the provision of incentives for the reduction of greenhouse gas emissions. ${ }^{83}$ Furthermore, 300 millions of allowances had been reserved for new entrant undertakings until December 2015.84

The New Directive's shift in the approach of allocation method had been welcomed, as it utilises the best available market-based instrument in terms of, compared witch allocation through grandfathering, providing the "bighest level of environmental and allocative efficiency, transparency and simplicity.' 85 Further advantage of the third phase scheme is that the Community-wide cap ensured this transparency with the abolishment of national allocation plans, the elimination of insecurity for industrial actors on the methods of allocation and the common, harmonised method on which the basis of allowances can be calculated at an EU-level. ${ }^{86}$

Yet even in the third phase, $40 \%$ of the total quantity is to be allocated free of charge. ${ }^{87}$ The important question in relation to benchmarking arises in connection to selectivity. It had been outlined that the justifiability of the benchmarking system relies on the "objectivity, the scope of the adopted standards and the degree of homogeneity of abatement cost structures. " 88 Furthermore, the benchmarking approach is less capable of causing market distortions as every undertaking are subject to the same standards in the given sectors, and that these standards reflect marginal sector abatement costs. ${ }^{89}$

\footnotetext{
${ }^{81}$ Directive 2009/29/EC, Preamble, point 27.

82 Directive 2009/29/EC, Article 10.; Cf.: Fodor László: A CO 2 leválasztásának és tárolásának (CCS) nemzetközi vetületei, In: Raisz Anikó (edit.): A nemzettö̈zi környezetjog aktuális kibivásai, Miskolc, Miskolci Egyetem, 2012, 51-61.

${ }_{83}$ Directive 2009/29/EC, Article 10a, point 1., para 3.

${ }^{84}$ Directive 2009/29/EC, Article 10a, point 8.

85 Guendalina Catti De Gasperi: Making State Aid Control "Greener": The EU Emission Trading System and its Compatibility with Article 107 TFEU, European State Aid Law Quarterly, 2010/9, 797.

${ }^{86}$ European Commission: European Emission Trading Scheme Handbook, 44.

87 Dirk Böhler: The EU Emission Trading Scheme - Fixing a Broken Promise; Environmental Law Review, 2013/15, 97.

${ }^{88}$ De Gasperi 2010, 803.

${ }^{89}$ De Gasperi 2010, 804.
} 
The issue of carbon leakage will still remain an issue to be tackled by the European legislator, as auctioning would only remain the most environmentally efficient approach, if it was applied at a global scale. ${ }^{90}$ In such cases only those countries pose a threat, where the level of cap at national level - for example part of a regional or universal cooperation - is not defined, as if the cap imposed is sufficiently low in one state, undertakings will not relocate their production there. ${ }^{91}$ The issue can arise from unilateral definition of caps, or from the unilateral tightening of such caps, which could be prevented by cross-border adjustments. ${ }^{92}$ Concerning industrial sectors involving a high chance of carbon leakage, policy makers might provide some transitional support for emissions-intensive trade-exposed industries ${ }^{93}$ that can also amount to the provision of State aid.

It is still questionable whether the allocation of allowances for free in sectors facing significant risk of carbon leakage would remain a sustainable solution. By the adoption of the New Directive, serious concerns were expressed with the further provision of free allowances, as they have the capability to affect competition in the given industrial sectors. Under the issue of carbon leakage, clearly, two huge interests collide: whether it is better to provide State aid and have undertakings within the European Union with a gradual decrease of aid involvement or to stick to the polluter-pays principle and face a larger amount of carbon leakage in the different industrial sectors.

\section{Conclusions}

All in all, it is possible to come to the conclusion that the ETS can be seen as quite a controversial scheme leaving some questions doubtful, especially if we consider the basic reconcilability of State aid measures in the area of environmental law and the polluter-pays principle. It is quite visible that State aid consideration cannot be fully aligned with the strictly interpreted polluter-pays principle. The first question that arises is to whom does the polluter pay under the ETS? As undertakings had been granted allowances freely, they could deliberately capitalise it without having to take into account environmental concerns. By selling these allowances on the market, these allowances were capable of providing a polluter pays to another polluters approach, leading to the incoherency of the ETS with environmental principles, as the income capitalised was not necessarily invested into environmental protecting investments.

The most interesting characteristic of the scheme is that it is possible to argue that this method of granting cannot be considered as a State measure, as the free allocation is defined in the Directive. Theoretically, it could be a logical argument as measures executed under EU law cannot amount to State aid. Naturally, the directive had to be implemented at national level, yet it is a question how to qualify the national allocation plans under the Directive.

${ }^{90}$ De Gasperi 2010, 799.

91 OECD 2011, 174.

92 OECD 2011, 10-11.

93 OECD 2011, 123. 
As the NAPs are defined by the Member States on a discretionary basis that was subjected to the supervision by the Commission, it is hard to come to the conclusion that the granting of allowances is not imputable to Member States. Before the adoption of the Directive, as it has been exemplified, the Commission had accepted schemes in connection to greenhouse gas emissions on the basis of Article 107 (3)(c) due to their environmentally-friendly aims. After the adoption of the Directive, we could see a very sharp change in the Commission's approach. This swift change is attributable to the justification on the provision of free allowances at EU-level, yet with the $5 \%$ and later $10 \%$ of allowances for auctioning the Commission had been declaring NAPs incompatible with the State aid rules.

Furthermore, it is questionable whether and to what extent can the integration clause, defined under Article 11 TFEU, as environmental protection requirements must be integrated into the definition and implementation of the Union policies and activities; it plays an important role in such cases. This clause yet raises the question whether environment-specific state aid issues can be reconciled with the integration clause. If the environmental principles would be strictly followed under EU law, then it would not have been possible to grant allowances (as State aid) to undertakings. The State aid provisions in relation to the ETS can be a clear sing of the restriction of the prevalence of the integration clause. This view can be supported by Commission decisions, as before the establishment of the ETS, any aid granted to undertakings for greenhouse gas emission were considered as an aid, yet saved under paragraph (3). After the ETS Directive came into force with the free allocation, the status of the polluter-pays principle was clearly wavered, bearing the possibility of the distortion of competition in the different industrial sectors. This approach clearly shows that although environmental concerns gained significance over time, yet they are not capable of prevailing competition aspects, causing the main environmental principles and the integration clause to only have a limited significance. 


\section{SERES Eszter Lilla* \\ Az Európai Emisszió-kereskedelmi Rendszer megfeleltethetősége a szennyező fizet elvének valamint az állami támogatások szabályozásának**}

\section{Bevezetés}

Az elmúlt évtizedekben a klímaváltozás témaköre mind nemzetközi, mind pedig uniós szinten kiemelkedő jelentőségűvé vált, így a nemzetközi fejlődési tendenciákhoz igazodva kezdte meg e specifikus területen az Európai Unió is a szabályozás területén való előrelépést.

A közösségi politikák fokozatos bővülésével egyben felmerültek a környezeti problémák versenyjog tekintetében történő elemzése, különös tekintettel az állami támogatások szabályozására. E kérdés leginkább az Unió Kyotói Jegyzőkönyvhöz való csatlakozásával vált érdekessé, ezzel vállalva az üvegházhatású gázok kibocsátásának csökkentését a 2008-2012-ig terjedő kötelezettségvállalási időszakban. A csatlakozás olyan közösségi intézkedések elfogadásához vezetett, amelyek lehetővé tettek egy közös, uniós szintű fellépést az üvegházhatású gázok kibocsátásával szemben - ezzel párhuzamosan azonban megkérdőjelezhetôvé vált az EU-s szabályozás összeegyeztethetősége a szennyező fizet elvével.

A dolgozat az Európai Kibocsátás-kereskedelmi Rendszer alapvető problémáit elemzi a szennyező fizet elvének tükrében. E kérdéskör pedig az állami támogatások környezetvédelmi vonatkozásai körében elemezhető. Az elemzés fő célja, hogy megállapíthatóvá váljon vajon lehetséges-e egyensúlyt teremteni a környezetvédelmi megfontolások és a vonatkozó versenyjogi szabályok között vagy pedig e két terület közötti ellentét kizárja-e az egymás mellett történő alkalmazhatóságot az uniós emisszió-kereskedelmi rendszer tekintetében.

\section{A szennyező fizet elv jelentősége}

A szennyező fizet elve a Gazdasági Együttmúködési és Fejlesztési Szervezet (OECD) égisze alatt, 1972-ben egy gazdasági - mintsem környezetjogi - elvként került elfogadásra. E szerint „a sžennyezônek kell viselnie a hatóságok által megállapitott intézkedések azon költségeit, amelyek a környezet elfogadható állapotban történő megörzését célozza. Más szavakekal, az ilyen intézkedések költségének meg kell jelennie azon áruk vagy szolgáltatások árában, amelyek a termelés vagy fogyaszutás során a szennyezést okozzák.

\footnotetext{
* dr. jur., jogi szakreferens, Versenyjogi, Fogyasztóvédelmi és Szellemi Tulajdonjogi Föosztály, Igazságügyi Minisztérium, e-mail: eszter.seres.92@gmail.com

** A cikkben kifejtettek semmilyen formában sem tükrözik az Igazságügyi Minisztérium álláspontját, az abban foglaltakért kizárólag a szerző felel.
} 
Ezekhez az intézkedésekhez nem társulhatnak támogatások, amelyek jelentös torzulást okozhatnak a nemzetközi kereskedelemben és befektetésben." A szennyező fizet elve a környezeti források elérhetőségének korlátozottságára utal, amely szúkös jelleget a termelési folyamatokban is figyelembe kell venni annak érdekében, hogy azt a piac is híven tudja tükrözni. ${ }^{2}$ A nem megfelelő piaci korrekció esetén az ilyen elégtelenségek csak olyan állami intézkedések által igazíthatóak ki, amelyek a szennyezést okozó vállalkozások oldalán megfelelően tudják mutatni a környezeti romlást az áruk és szolgáltatások árában, ezáltal lehetővé téve a hatóságok által bevezetett és a szennyezések megelőzését és ellenőrzését célzó költségek allokációját, elősegítve a környezeti források ésszerű használatát valamint megelőzve a nemzetközi kereskedelem és befektetések torzulását. ${ }^{3}$

Az állami intézkedéseknek - különös tekintettel a környezetvédelemre különböző alkalmazási köre lehet: felmerülhetnek egy, a termelési folyamatokba be nem integrált költség felszámolása vagy a környezetvédelmi érdekek egyéb, állam általi támogatása során. ${ }^{4}$ Az elôbbi alkalmazási körbe tartozó esetekben a támogatás egy externália internalizálására szolgál. ${ }^{5}$ Ilyen értelemben, ezek az externáliák negatív természetűek, amely természet közgazdasági értelemben a piac tökéletes működésének hiányát eredményezve a közösség számára rossz vagy jó kimenetellel jár. ${ }^{6}$ Példaképp hozható egy vállalkozás által a termelés folyamata során okozott szennyezés, amely negatív externáliaként jelenik meg. ${ }^{7} \mathrm{Ez}$ az extetnália egyértelműen jelzi, hogy a vállalkozások termelési folyamatában - a bevitel során - környezeti források kerülnek felhasználásra. ${ }^{8}$

1 OECD: Recommendation of the Council on Guiding Principles concerning International Economic Aspects of
Environmental Policies, $\quad \mathrm{C}(72) 128, \quad 1972, \quad$ point $4 . ; \quad$ in: http://acts.oecd.org/Instruments/ShowInstrumentView.aspx?InstrumentID=4\&InstrumentPI $\mathrm{D}=255 \&$ Lang $=$ en $\&$ Book $=(11.10 .2016)$

2 OECD 1972, para. 2.; Lásd továbbá: Csák Csilla: Gondolatok a szennyező fizet elvének alkalmazási problémáiról, Miskolci Jogi Sz̨emle, 2011/klnsz, 31-45.

${ }^{3}$ Philippe Sands: Principles of International Environmental Law, Cambridge, Cambridge University Press, 2003, 281., https://doi.org/10.1017/CBO9780511813511; Bándi Gyula: A szennyezô fizet elv és a környezetre veszélyes tevékenységgel okozott károkra vonatkozó felelősségi szabályok európai trendjei, in: Margitán Éva et al (szerk.): Nyugat-európai hatások a magyar jogrendszer fejlódésében, Budapest, ELTE-ÁJK, 1994, 136-162.

${ }^{4}$ Hyun-Jing Kim: Subsidy, Polluter Pays Principle and Financial Assistance; Journal of World Trade Law, 2000/34., 119.; Nagy Zoltán: Környezeti adózás szabályozása a környezetpolitika rendszerében, Miskolc, Miskolci Egyetem, 2013, 44-77.

${ }^{5}$ Hyun-Jing Kim 2000, 120-121.

${ }^{6}$ Hans Vedder: Competition Law and Environmental Protection in Europe; Towards Sustainability?, Groningen Europa Law Publishing, 2003, 15.; Nagy Zoltán: The Instruments of the Environmental Policy's Economic Regulation with a Particular Regard to the Hungarian System, Lex Et Scientia, 2014/1, 77-88.

${ }^{7}$ Moritz Lorenz: An Introduction to EU Competition Law, Cambridge, Cambridge University Press, 2013, 23-24., https://doi.org/10.1017/CBO9781139087452; Bándi Gyula: Környezetjog, Budapest, Szent István Társulat, 2011, 56-58.

8 OECD: Economic Instruments for the Environmental Protection, Working Paper No. 92, 1989, in: http://www.oecd.org/dev/1919252.pdf (20.10.2016), 5. 
Abból eredően, hogy a termelés során okozott környezeti károsodás a vállalkozás oldalán nem jelenik meg költségként, ezért a piaci oldalon a környezetromlás nem jelenik meg szükségszerűen a szennyezés idején, hanem az ebből eredő a negatív hatások csak társadalmi szinten jelentkeznek. ${ }^{9}$

Uniós szinten a szennyező fizet elvét az Európai Unió Múködésérôl Szóló Szerződés (a továbbiakban: EUMSz) 191. cikk (2) bekezdése is meghatározza, amely többek között kimondja, hogy az Unió környezetvédelmi politikája a szennyező-fizet elvén alapul.

\section{Az állami támogatások tekintetében alkalmazandó szabályok}

\subsection{Az állami intézkedések állami támogatásként való minősítése}

A környezetvédelem területén nyújtott állami támogatások általános célja, hogy az állami intézkedések bevezetése által biztosítva legyen a környezet olyan magasabb szintű védelme, mint ami a támogatás bevezetése nélkül elérhető volna. ${ }^{10} \mathrm{Az}$ ilyen támogatások nélkül a piac nem volna képes a források hatékony allokációjára, lehetôvé téve ezáltal a negatív externáliák megjelenését.

Az állami támogatások nyújtására vonatkozó általános tilalmat ha a Szerződések másként nem rendelkeznek - az EUMSz 107. cikk (1) bekezdése fekteti le. ${ }^{11}$ Azon állami intézkedések, amelyek bizonyos vállalkozások számára vagyoni előnyt biztosítva megfelelnek adott kritériumoknak, állami támogatásnak fognak minősülni. E kritériumok pedig a következőek: az állami intézkedés tekintetében állami források átruházására kell, hogy sor kerüljön, amely előnyt vállalkozások számára kell biztosítani, és amelynek szelektívnek kell lennie, megvalósítva ezzel tagállamok közötti verseny torzulását. ${ }^{12}$

\footnotetext{
${ }_{9}$ Vedder 2003, 15.; Lásd továbbá: Bobvos Pál - Csák Csilla - Horváth Szilvia - Olajos István Prugberger Tamás: A szennyező fizet elv megjelenése a mezőgazdaságban, Journal of Agricultural and Environmental Law, 2006/1, 29-55.

${ }^{10}$ Conor Quingly: European State Aid Law and Policy, Oxford, Hart Publishing, 2009, 271.; Olajos István: A vidékfejlesztési jog kialakulása és története, Miskolc, Novotni Kiadó, 125-126. Guidelines on State aid for environmental protection and energy 2014-2020, OJ C 200, 2014, para. 30. in: http://eur-lex.europa.eu/legal-content/EN/TXT/?uri=CELEX\%3A52014XC0628(01) (19.10.2016)

11 E cikk szerint: (1) Ha a Szerződések másként nem rendelkeznek, a belső piaccal összeegyeztethetetlen a tagállamok által vagy állami forrásból bármilyen formában nyújtott olyan támogatás, amely bizonyos vállalkozásoknak vagy bizonyos áruk termelésének előnyben részesítése által torzítja a versenyt, vagy azzal fenyeget, amennyiben ez érinti a tagállamok közötti kereskedelmet.

${ }^{12}$ Legih Hancher - Tom Ottervanger - Piet Jan Slot: EC State Aids, London, Sweet \& Mawell, 2006, 500 .
} 
Az Európai Unió Bíróságának esetjoga nem ad pontos meghatározást az állami támogatások pontos fogalmának tekintetében, inkább leírja azokat az intézkedéseket és döntéseket, amelyek során „a tagállamok saját gazdasági vagy társadalmi céljaik elérése érdekében egyoldalú és autonóm döntésük keretében vállalkozásoknak vagy más személyeknek bizonyos forrásokat vagy más elönyöket nyújtanak, amely források e vállalkozások vagy szemébyek gazdasági vagy társadalmi céljai elérésének támogatására szolgálnak." "13

Először, az intézkedésnek az állami források vállalkozásra törtnő ruházása feltételének kell teljesülnie, amely elem körébe „kizárólag azok a kedvezmények tartoznak, amelyeket közvetve vagy közvetlenül állami forrásokból finanszíroznak."14 A ‘tagállam által nyújtott támogatás' és az 'állami forrásból származó’ támogatás között tett megkülönböztetés nem azt jelzi, hogy minden állam által nyújtott előny - amelyet állami forrásból vagy máshonnan finanszíroznak - állami támogatásnak minősül; mindössze arra szolgál, hogy e fogalmi körbe vonjon be bármely olyan előnyt, amelyet „az állam közvetlenül vagy - közvetve - az állam által kijelölt vagy létrehozott köz- vagy magánszervezet nyújt."15 Mindemellett, az állami támogatás fogalma nem csak pozitív előnyök - mint például támogatások, kölcsönök vagy vállalkozások tőkéjébe történő közvetlen befektetés - nyújtását foglalja magában, hanem olyan állami beavatkozásokat is, amelyek csökkentik a vállalkozás költségvetésének kialakítása során eleve felmerülő pénzügyi terheket. ${ }^{16}$ Másodsorban, az intézkedésnek az államnak betudhatónak kell lennie. ${ }^{17}$ E tekintetben, amikor az intézkedést és a kifizetést egy olyan testület hozza, amely a hatóságok irányítása és utasítása alatt áll, akkor e tevékenység a tagállamnak betudható, mivel az egy egyébként rendes körülmények között elérhető nyereségről mond le. ${ }^{18}$ Harmadrészt pedig az ilyen források nyújtását hatóságoknak jóvá kell hagynia. ${ }^{19}$

\footnotetext{
13 A Bíróság C-61/79. sz. Amministrazione delle Finanze Stato kontra Devankit Italiana ügyben 1983. november 9-én hozott ítélete (EBHT 1980-01205.) para. 31.

${ }^{14}$ A Bíróság C-379/98. sz. PreussenElektra AG kontra Schleswag AG ügyben 2001. március 13 án hozott ítélete (EBHT 2001., I-02099.) para. 58.

${ }^{15}$ A Bíróság C-379/98. sz. PreussenElektra AG kontra Schleswag AG ügyben 2001. március 13án hozott ítélete (EBHT 2001., I-02099. o.) para. 58.

${ }^{16}$ A Bíróság C-126/01. sz. Ministère de l'Économie, des Finances et de l'Industrie kontra GEMO SA ügyben 2003. november 20-án hozott ítélete (EBHT 2003.,I-13769.) para. 28.

17 A Bíróság C-482/99. sz. Franciaország kontra Bizottság (Stardust Marine) ügyben 2002. május 16-án hozott ítélete (EBHT 2002., I-04397.) para. 68.

18 A Bíróság C-67/85. sz. Kwekerij Gebroeders Van der Kooy BV and Others kontra Európai Közösségek Bizottsága ügyben 1998. február 2-án hozott ítélete (EBHT 1988-00219.) para. 220.

19 Vedder 2003, 285.
} 
A második követelmény tekintetében - miszerint az előnyt egy vállalkozás számára kell nyújtani - az EUMSz 107. cikk (1) bekezdése lefedi mind a magán- mind pedig a közvállalkozásokat. ${ }^{20} \mathrm{Az}$ uniós versenyjog szemszögéből bármely olyan személy vagy szervezet, amely gazdasági tevékenységet folytat vállalkozásnak minősül. ${ }^{21}$ Így „a jogalany jogi helyzetére és a finanszírozási módjára való tekintet nélkü̈l,'22 a hangsúlyt annak a kérdésnek a vizsgálatára kell fektetni, hogy a vállalkozás az adott piacon árut vagy szolgáltatást kínál, ${ }^{23}$ ahol a haszon elérésének szükségessége sem merül fel. ${ }^{24}$

A harmadik kritérium, amelynek szükséges teljesülnie ahhoz, hogy egy intézkedés állami támogatásnak minősüljön, a szelektivitás. Általánosságban véve a tagállamokat nem lehet arra kötelezni, hogy tartózkodjanak olyan intézkedések bevezetésétől, amelyek az általános gazdaságpolitika körébe tartoznak, ${ }^{25}$ értve ezen azt, hogy a szelektivitás követelménye csak akkor teljesül, hogyha egy „adott kötelezó rendszerben egy állami intézkedés bizonyos vállalkozásoknak vagy bizonyos áruk elöállitásának. kedvez olyan más vállalkozásokkal szemben, amelyek az intézkedés célja tekintetében a támogatásban részesüló vállalkozással összehasonlitható jogi vagy ténybeli helyzetben vannak. '26 Abban az esetben, amikor a pénzügyi segítséget nyújtó testületnek olyan mozgástere van, amely lehetővé teszi számára, hogy megválassza az előnyben részesülők körét vagy a pénzügyi támogatás nyújtásának feltételét, akkor e támogatás nem tekinthető egy általános gazdasági intézkedésnek, ${ }^{27}$ így a támogatást nyújtó hatóságok oldalán megjelenő diszkrecionális jogkör a szelektivitás követelményének fennállására enged következtetni. ${ }^{28}$

Végül a tagállamok közötti kereskedelemre való hatás követelménye képezi a negyedik feltételt, ami annyit tesz, hogy az állami támogatásnak alkalmasnak kell lennie a verseny torzítására és arra, hogy tagállamok közötti kereskedelmet is érintse.

\footnotetext{
20 A Bíróság C-78/76. sz. Steinike \& Weinlig kontra Német Szövetségi Köztársaság ügyben 1977. március 22-én hozott ítélete (EBHT 1977-00595.) para. 18.

${ }^{21}$ Várnay Ennő- Papp Mónika: Az Európai Unió joga, Budapest, Complex Kiadó, 2013, 713. Lásd továbbá:

22 A Bíróság C-41/90. sz. Klaus Höfner and Fritz Elser kontra Macrotron GmbH. ügyben 1991. április 23-án hozott ítélete (EBHT 1991., I-01979.) para.21.

${ }^{23}$ Várnay - Papp 2013, 713-714.

${ }^{24}$ Európai Bizottság: Bizottsági közlemény az Európai Unió működésérôl szóló szerződés 107. cikkének (1) bekezdésében említett állami támogatás fogalmáról, C 262/01, 2016, para. 9., in http://eur-lex.europa.eu/legal-

content/EN/TXT/PDF/?uri=CELEX:52016XC0719(05)\&from=EN (22.10.2016)

25 Várnay - Papp 2013, 1004.

26 A Bíróság C-409/00. sz. Spanyol Királyság kontra Európai Közösségek Bizottsága ügyben hozott 2003. február 13-i ítélete (EBHT 2003., I-01487.) para. 47.

27 A Bíróság C-256/97. sz. Déménagements-Manutentuin Transport SA ügyben hozott 1999. június 29-i ítélete (EBHT 1999., I-03913.) para. 27.

${ }^{28}$ Vedder 2003, 293.
} 


\subsection{Az állami támogatások közös piaccal való összeegyeztethetősége}

Egy állami támogatásnak minősülő környezetvédelmi intézkedés abban az esetben minősül jogszerűnek, hogyha az EUMSz 107. cikk (3) bekezdésének c) pontja alapján összeegyeztethetôvé válik a belső piaci szabályokkal. Az EUMSz 107. cikk (3) bekezdése alapján a Bizottság diszkrecionális jogkörrel rendelkezik annak eldöntése tekintetében, hogy egy támogatás összeegyeztethetô-e a belsô piaci szabályokkal vagy sem. Ezt a diszkrecionális jogkört jelenleg a Bizottság csoportmentességi rendelete ${ }^{29}$ korlátozza, amely alapján a környezet védelmét célzó állami támogatások hangsúlyos pozícióba kerülhettek a szennyező fizet elvének párhuzamos érvényesülése mellett.

Miután az állami támogatások szabályozása körében a környezetvédelem az egyik fő horizontális célkitűzés, ${ }^{30}$ ezért a Bizottság Iránymutatásokat bocsát ki a környezetvédelmi tárgyú állami támogatások tekintetében, amely jelenleg a 2014-2020-ig tartó időszakra vonatkozik (a továbbiakban: Iránymutatás). Általában véve az Iránymutatás célja a környezet védelme olyan tevékenységek támogatásán keresztül, amelyek a környezeti vagy természeti erőforrásokban keletkezett károk megelőzését vagy helyreállítását célozzák, valamint az erőforrások használatát segítik elő. ${ }^{31}$ Az Iránymutatás átláthatóságot biztosít a tagállamok és a vállalkozások számára, amelyek így képesek lesznek azon kritériumok betartására, amelyeknek meg kell felelniük, és amelyeket a Bizottság a belső piaci szabályokkal való összeegyeztethetőség vizsgálata során alkalmazni fog. ${ }^{32}$ Azonban az Iránymutatás nem egy általános összeegyeztethetőségi szabályt határoz meg az általa lefedett körben, hanem csak vélelmezi az összeegyeztethetőséget olyan támogatások számára, amelyek megfelelnek a benne foglalt kritériumoknak.

Az Iránymutatás egy környezetvédelmi támogatás pozitív vagy ösztönző hatásának meglétére fekteti a hangsúlyt, amelynek az összeegyeztethetőség érdekében kell fennállni. Ez az ösztönző hatás arra utal, hogy a támogatásnak késztetnie kell az abban részesülőt a piaci magatartása megváltoztatására a környezet védelemének növelése érdekében - amelyet a támogatás nélkül egyébként nem vállalt volna. ${ }^{33}$ Ennek a hatásnak minden nyújtott támogatásban jelen kell lennie, ezáltal biztosítva a környezet védelmének adott helyzetben alkalmazandó magasabb szintjét. ${ }^{34}$

\footnotetext{
29 A Bizottság 651/2014/EU rendelete (2014. június 17.) a Szerződés 107. és 108. cikke alkalmazásában bizonyos támogatási kategóriáknak a belső piaccal összeegyeztethetővé nyilvánításáról

30 Várnay - Papp 2013, 1014.

${ }^{31}$ Hancher - Ottervanger - Slot 2006, 508.

32 Volker Zuleger: Compatibility of State Aid pursuant to Article 87 (3) EC, in: Martin Heidenhain (edit.): European State Aid Law; Munich, Beck, Hart and Namos Publishing, 2010, 270.

33 2014-es Iránymutatás, para. 49.

34 Phedon Nicolaides - Maria Kleis: A Critical Analysis of Environmental Tax Reduction and Generation Adequacy Provisions in the EEAG 2014-2020, European State Aid Law Quarterly, 2014/14, 639-640.
} 
Azonban egy támogatást nem lehet szükségszerűnek tekinteni azon az alapon, hogy növeli a környezet védelmének szintjét. ${ }^{35} \mathrm{Az}$ olyan intézkedések, amelyeknél a negatív hatások nyilvánvalóan meghaladják a támogatás által elérhetô pozitív hatásokat, nem tekinthetőek a belső piaci szabályokkal összeegyeztethetőnek. ${ }^{36}$ A negatív és pozitív hatásokat a Bizottság vizsgálata során mérlegelni fogja és meghatározza, hogy a támogatás által keletkező piaci torzulások hátrányosan olyan mértékben érintik-e a kereskedelmet, amely ellentétes a közös piaci érdekekkel. ${ }^{37}$ Ha a negatív hatások meghaladják az általa elérhető pozitív hatásokat, akkor a támogatás nem lesz végrehajtható, amíg túlnyomó pozitív hatás fennállása esetén a tagállam jogosult lesz a támogatás a vállalkozások számára történő nyújtására.

\section{Az Európai Emisszió-kereskedelmi Rendszer}

A nemzetközi környezetjog tekintetében - az ENSZ Klímaváltozási Keretegyezményéhez csatolt - Kyotói Jegyzőkönyv 1997-es elfogadásával az iparosodott gazdaságok általi üvegházhatású gázkibocsátások mennyiségi korlátozásának alapjai kerültek lefektetésre. ${ }^{38}$ A Jegyzőkönyv egy globális piacot ${ }^{39}$ állít fel az iparosodott államok számára a kibocsátási engedélyek kereskedelmére.

A Jegyzőkönyv a 17. cikkében határozza meg az emisszió-kereskedelem alapvető követelményeit. A dokumentum 3. cikke célkitűzésként fogalmazza meg a szerződő államok általi üvegházhatású gázok kibocsátásának csökkentését oly módon, hogy a 2008-tól 2012-ig terjedő kötelezettségvállalási időszakban e gázok összesített kibocsátásai az 1990. évi szinteknél legalább 5 százalékkal alacsonyabbak legyenek. Ha pedig a szerződő felek nem érik el a B Mellékletbe megszabott vállalásuk felső határát, akkor a kijelölt mennyiségi egységekkel, igazolt kibocsátás-csökkentésekkel, kibocsátás-csökkentési egységekkel és eltávolítási egységekkel jogosultak kereskedni. ${ }^{40}$

\footnotetext{
${ }^{35}$ Quingley 2009, 291.

36 2014-es Iránymutatás, para. 94.

${ }^{37}$ Quingley 2009, 293.

38 Patricia Birnie - Alan Boyle - Catherine Redgwell: International Law and the Environment, Oxford, Oxford University Press, 2009, 360-361.

39 OECD: Emission Permits and Competition, DAF/COMP(2010)35, 2011, In: http://www.oecd.org/competition/sectors/48204882.pdf, (10.11.2016) 32.; Lásd továbbá: Fodor László: A kibocsátási egységek kereskedelme: Európajogi alapok - a német és a magyar nemzeti szabályozás 2004-2012 között, Journal of Agricultural and Environmental Law, 2013/14, 352.

${ }^{40}$ Birnie - Boyle - Redgwell 2009, 367.
} 
2001-ben a Bizottság kiadta az Európai Unión belüli üvegházhatású gázok emisszió-kereskedelmére vonatkozó Zöld Könyvét, ${ }^{41}$ amely az Európai Emissziókereskedelmi Rendszerre vonatkozó elméleti kereteket és alapvető elképzeléseket rögzítette. A Bizottság már akkor arra az álláspontra helyezkedett, hogy a Kyotói Jegyzőkönyvnek való megfelelés érdekében bevezetett tagállami intézkedések állami támogatásnak minősülhetnek, azonban az idő tájt még korainak látta, hogy az ilyen támogatás jóváhagyására vonatkozó feltételek lefektetésre kerüljenek. ${ }^{42}$

A Zöld Könyvben a Bizottság kiemelte egy olyan rendszer létrehozásának szükségességét, amely az Európai Emisszió-kereskedelmi Rendszeren belül egyenlő mértékű teherelosztást határoz meg minden szektor és résztvevő számára a rendszeren kívül maradtakhoz képest. Az emisszió kereskedelmi rendszer létrehozása szempontjából a Bizottság két különböző piaci alapú eszköz alkalmazását tartotta megfontolandónak: az aukció útján történő értékesítést vagy pedig a leszármaztatás módszerét - másképp a kibocsátási egységek ingyenes átruházását. ${ }^{43}$ Az aukció útján történő értékesítés önmagában véve összhangba hozható a szennyező fizet elvével, mivel az aukcióból származó bevételeket az állam többféleképp hasznosíthatja a környezeti károk csökkentése és a környezet védelmének növelése érdekében. Mindemellett a teljesítmény alapú értékelés is számításba került a rendszer kilétének meghatározása során, miután a leszármaztatás módszere csak a múltbéli kibocsátási adatok alapján tudott megoldást nyújtani, amely kizárólag a legnagyobb kibocsátók számára bizonyul kifizetődőnek - nem pedig azon vállalkozások számára, amelyek már előzetesen is a kibocsátás-csökkentés irányába mutató, a vállalkozáson belüli különböző környezetvédelmi intézkedéseket vezettek be. Ezáltal a teljesítményértékelés egy kifejezetten jó alapot tud biztosítani a vállalkozások termelése során környezetkárosító létesítménye tekintetében meghatározandó teljesítmény-sztenderdek felállításához. ${ }^{44}$

\footnotetext{
${ }^{41}$ Európai Bizottság: Green Paper on greenhouse gas emissions trading within the European Union, $\mathrm{COM} / 2000 / 0087, \quad$ in: http://eur-lex.europa.eu/legalcontent/EN/TXT/?uri=celex\%3A52000DC0087 (10.11.2016) point 7.1.

${ }^{42}$ Európai Bizottság: European Emission Trading Scheme Handbook. 71.

43 A Zöld Könyvben a leszármaztatás úgy került meghatározásra, mint amely szigorú értelemben véve nem egy realizálható eszköz térítésmentes átruházásának fogalmához kapcsolódik, hanem inkább egy történeti alapon fennálló jogot testesít meg - mint például szavazati jog -, amelyet át lehet ruházni a jogutódra vagy egy jogi személy folytatólagos fennállása során akár meg is tarthat, és amely ezen előre meghatározott korlátokon kívül nem átruházható. Lásd továbbá: Fodor László: A kibocsátási egység - új típusú vagyoni értékủ jog a klímavédelem szolgálatában, Collectio Iuridica Universitatis Debreceniensis, 2008/7, 161-200.

${ }^{44}$ Európai Bizottság: Green Paper 2000, 7.2.2. pont
} 
Végül, a Zöld Könyvben lefektetésre került gondolatok a 2003/97/EK irányelv elfogadásához vezettek, ezzel létrehozva az Európai Emisszió-kereskedelmi Rendszert (a továbbiakban: EKR). ${ }^{45} \mathrm{Az}$ EKR létrehozásának fő célja az üvegházhatású gázok kibocsátásának költséghatékony és gazdaságilag eredményes csökkentésének ösztönzése. ${ }^{46}$ A rendszer a felső határérték meghatározási és kereskedelmi sémát vagy abszolút rendszert ${ }^{47}$ - követi, amely az üvegházhatású gázok kibocsátásának a rendszerben részt vevők irányában kötelező felső határérték meghatározását jelenti. ${ }^{48}$ A rendszer lehetôséget nyújt a szennyező tevékenységet folytató vállalkozások számára, hogy kibocsátási jogokat vásároljanak meg olyan más vállalkozásoktól, amelyek alacsonyabb költségen csökkenteni tudják a kibocsátásukat. ${ }^{49}$

Az uniós emisszió kereskedelmi rendszer első szakasza 2005-2007-es időintervallum, valamint a második 2008-2012-es szakasz keretében minden tagállam eldönthette, ${ }^{50}$ hogy az adott időszakra hány egységet oszt ki összesen, valamint az egyes létesítmények üzemeltetőinek tételesen. ${ }^{51} \mathrm{Az}$ első és második szakaszban a kibocsátási engedélyeket ellentételezés nélkül nyújtották a tagállamok a szennyezők számára, miután feltételezésre került, hogy a kibocsátási jogok ingyenes átengedésével jelentősen lecsökkenthető a létesítményeknél jelentkező költségek, ezzel párhuzamosan pedig megkérdőjelezhető módon - megtartva a kibocsátás csökkentésére irányuló gazdasági ösztönzőket. ${ }^{52}$ Emellett az első szakaszban az emisszió-kereskedelmi rendszer lehetővé tette a tagállamok számára, hogy a rendelkezésükre álló emisszió-kereskedelmi engedélyek 5\%-át aukció útján értékesítsék, amíg a második szakaszban az aukció mértékét 10\%-ra emelték fel.

45 Az Európai Parlament és a Tanács 2003/87/EK irányelve (2003. október 13.) az üvegházhatást okozó gázok kibocsátási egységei Közösségen belüli kereskedelmi rendszerének létrehozásáról és a 96/61/EK tanácsi irányelv módosításáról. Az uniós emissziókereskedelmi rendszerről lásd: Horváth Szilvia: A kibocsátási jogok kereskedelmének nemzetközi báttere, közösségi szabályozásának alakulása, PhD-értekezés, SZTE, 2007; valamint Horváth Szilvia: Az Európai Közösség éghajlatváltozás elleni politikájának kezdeteiről, Journal of Agricultural and Environmental Law, 2007/2, 20-40.

46 2003/87/EK irányelv, 1 cikk

47 Suzanne Kingston: The role of Environmental Protection in EC Competition Law and Policy, PhD thesis, 2009;

in:

https://openaccess.leidenuniv.nl/bitstream/handle/1887/13497/Suzanne+Kingston $+\mathrm{PhD}+\mathrm{Th}$ esis.pdf?sequence $=1$ (11.11.2016) 50.; Nagy Zoltán: Az emisszió-kereskedelmi rendszerek szerepe a környezetpolitikában, In: Raisz Anikó (szerk.): A nemæętköæi körmyezetjog aktuális kihivásai, Miskolc, Miskolci Egyetem, 2012, 118-128.

${ }^{48}$ Európai Bizottság: European Emission Trading Scheme Handbook. 16.

49 OECD: Emission Trading Systems, in: http://www.oecd.org/env/toolsevaluation/emissiontradingsystems.htm, (10.11.2016)

${ }^{50}$ Fodor László: A kibocsátási egységek kereskedelmi rendszerének bevezetése Magyarországon, Publicationes Universitatis Miskolciensis Series Juridica et Politica, 2007/25/1, 289-316.

${ }^{51}$ EKR Irányelv 11. cikk

52 OECD 2011, 173. 
Emellett bevezetésre került a kibocsátási engedély kibocsátható mennyiségi egységekkel történő alátámasztásának kötelezettsége, miután a rendszeren belüli ingyenes vagy piaci ár alatti allokáció állami támogatás lehetőségét rejtette magában. ${ }^{53}$

Az irányelv által felállított rendszer egyik sajátossága, hogy III. Mellékletében csak a nemzeti kibocsátási érték felső határát szabta meg, amelynek a Kyotói Jegyzőkönyvben meghatározott célkitűzésekkel kellett összhangban állnia. Másik sajátossága, hogy - a 10. cikke alapján - az első szakaszban a kibocsátási jogok 95\%-a, míg a második szakaszban azok 90\%-a leszármaztatás útján, ingyenesen került kiosztásra. Annak ellenére, hogy a Zöld Könyvben a Bizottság az aukció útján történó értékesítést tartotta a legkedvezőbb megoldásnak, végül a tagállamok számára jelentősebb mozgástér biztosítása részesült előnyben. Továbbá maga az irányelv nem biztosított semmilyen iránymutatást az állami támogatásokra vonatkozó rendelkezések tekintetében, III. Mellékletében mindössze kifejezésre juttatta, hogy a nemzeti kiosztási tervek a Szerződés követelményei és különösen annak 87. és 88. cikke (jelenleg EUMSz 107. és 108. cikke) értelmében nem tehettek különbséget a vállalkozások és ágazatok között oly módon, hogy bizonyos vállalkozásokat vagy tevékenységeket indokolatlan előnyben részesítsenek.

Mivel a szennyező fizet elve már az irányelv elfogadásakor is az uniós környezetvédelmi politika részét képezte, így megkérdőjelezhető, hogy az első és második szakaszban véghezvitt ellenérték nélküli allokáció mennyiben tekinthető a környezetvédelmi megfontolásokkal összeegyeztethetőnek. Szigorúan értelmezve a kibocsátási jogok ingyenes átengedésével a tagállamok arra vállalkoztak, hogy lemondanak olyan állami bevételekről, amelyeket a környezet védelmének növelésére lehetett volna fordítani. Egy másik szemszögből történő megközelítés szerint úgy is lehet azonban érvelni, hogy csak az első és második szakaszban az aukció útján értékesíthető 5, illetve 10\% tekinthető a tagállam által oót megillető bevételről való lemondásnak, mivel csak e tekintetben volt számukra bizonyos mértékű mozgástér biztosítva. Továbbá, miután az irányelv III. Melléklete csak általános utalást tett a Szerződésben szabályozott állami támogatásokra vonatkozó szabályokra, az emisszió kereskedelmi rendszer keretében tett tagállami intézkedések állami támogatásként való minősítésének kérdése továbbra is nyitva maradt. Elméletileg a rendszer nem egyértelműen összeegyeztethető az állami támogatásokra vonatkozó szabályozással, mivel a kereskedésre alkalmas kibocsátási engedélyek ellentételezés nélkül kerültek kiosztásra a vállalkozások között, amíg az aukció megoldását választva az így befolyó összegek az állami források részévé válhattak volna. Ezáltal az uniós emissziókereskedelmi rendszer alatt a tagállamok lemondtak ezekről a bevételekről és azok a vállalkozások, amelyek korábban csökkentették a kibocsátási szintjüket könnyen tőkésíthették az általuk igénybe vett kibocsátási jogosultságot meghaladó kibocsátási egységeket.

${ }^{53}$ Kingston 2009, 255. 
Az állami támogatások fogalomkörét elemezve az EKR első és második szakasza a következőekben foglalható össze. Az előző fejezetben rögzített feltételek alapján a támogatást a tagállamnak kell nyújtania vagy pedig közvetve állami forrásokból kell származnia, amelyet egy állami szerv vagy az állam által létrehozott magánszervezet nyújt. Lorenz elemzése alapján, az EKR felállítása során kialakult vélemények reprezentatív hányada arra az álláspontra helyezkedett, hogy a rendszer kizárja az állami támogatás létét, mivel a kibocsátási egységek kereskedelméből származó előnyök a magánszemélyek közötti kereskedelemből erednek. ${ }^{54}$ A szerzők egy másik csoportja, viszont ellenérvként fogalmazta meg, hogy a kibocsátási engedélyek által megtestesített potenciális bevételek megfeleltethetőek az állami forrásokból származó támogatásnyújtás követelményének. A második kritérium tekintetében meg kell vizsgálni, hogy a gazdasági előnyt egy adott vállalkozásnak juttatja-e az állam vagy állami szerv. Miután azok a vállalkozások, amelyek az emisszió-kereskedelmi rendszer által érintett iparágak résztvevői voltak, ezért azáltal jutottak előnyhöz a rendszeren belül, hogy bármilyen ellentételezést kellett volna fizetniük a kibocsátási jogok érdekében, ezáltal egy olyan előnyt biztosítottak számukra, amelyet a későbbiekben teljes mértékben fel tudtak használni vagy akár továbbértékesíthettek más résztvevőknek. Harmadrészt a szelektivitás kérdését a lefedett ipari szektorok é a résztvevők oldaláról kell vizsgálni. Maga a rendszer nem tekinthető szelektívnek azon az alapon, hogy csak bizonyos iparágakat fed le - ennek ellenére a Bizottság gyakorlatában mégis találkozhatunk olyan ügyekkel, ahol éppen ilyen érvelési alapokon talál egy emissziókereskedelmi rendszert szelektívnek az uniós szerv. ${ }^{55}$ A szelektivitás problémája a rendszer alapjaiban is megtalálható. Azáltal, hogy a tagállamoknak ellentételezés nélkül vagy aukció útján a rendszer felállításakor, majd pedig a második fázis kezdetén szét kellett osztaniuk a kibocsátási egységeket, ezáltal a később belépőknek már a létrehozott piacon kellett megvenniük a kibocsátásukhoz szükséges engedélyt. ${ }^{56}$ Végül az utolsó kérdéskör a tagállamok közötti verseny torzítására vonatkozik, amely probléma meglétét még az EKR Irányelv előtt létrehozott emisszió-kereskedelmi rendszerek vetettek fel. ${ }^{57}$ Továbbá a verseny torzítására vonatkozó kitétel elképzelhető egy olyan energetikailag hatékony vállalkozás tekintetében is, amely még a rendszerben való részvétele előtt különböző kibocsátás csökkentési lépéseket tett, és a későbbiekben elfogadott nemzeti kiosztási tervek ezeket a törekvéseket nem vették figyelembe. ${ }^{58}$

\footnotetext{
54 Moritz Lorenz: Emission Trading - State Aid Dimension, European State Aid Law Quarterly, 2004/3, 401.

${ }_{55}$ Lorenz 2004, 402.

56 2014-es Iránymutatás, para. 235.

57 A Bizottság N 416/2001 sz. ügyben hozott 2001. november 28-i határozata (Egyesült Királyság emisszió-kereskedelmi rendszere), 9.

${ }^{58}$ Lorenz 2004, 402.
} 


\section{A holland $\mathrm{NO}_{\mathrm{x}}$ kibocsátás kereskedelemi rendszer}

A holland rendszer még az EKR Irányelv elfogadása előtt került felállításra, azonban az a 2001/81/EK irányelv alapján került elfogadásra, amely az egyes levegőszennyező anyagokra előírt nemzeti összkibocsátási határértékeket határozta meg. Az irányelv alatt a holland kibocsátási felső határérték 260 kilotonnában volt meghatározva, amelyet 2010-ig kellett megvalósítani. ${ }^{59}$ A holland hatóságok értékelése alapján az így meghatározásra került kibocsátási követelmények, valamint a kibocsátási határértékekre vonatkozó szabályozás elégtelen eszköznek bizonyult a 2010-es cél eléréséhez. ${ }^{60}$ Ezáltal részükről felmerült egy új rendszer kialakításának szükségessége. Az így felállítandó rendszerben történő részvétel kötelező volt és minden vállalkozásnak $\mathrm{NO}_{\mathrm{x}}$ kibocsátását a rendszerhez kellett igazítania a létesítményeikben való csökkentéskibocsátás által vagy pedig kibocsátás csökkentési engedélyek vétele vagy teljesítmény általi elérése által, valamint a két opció együttes alkalmazásával.61 A kötelező megfeleléssel párhuzamosan a kereskedelem opcionális volt, amely alatt a résztvevő létesítmények szabadon eldönthették, hogy kívánnak-e ezzel a lehetőséggel élni, és ha igen milyen mértékben akarnak a kibocsátási egységekkel kereskedni az adott, illetve az elkövetkező években. Magát a rendszert a 'dinamikus felső-határérték' jellemezte. ${ }^{62}$ Ebben a felső-határérték nem volt meghatározva, ezért a rendszerben lehetőség volt a fokozatos növekedésre. A holland hatóságok azonban megszabták, hogy az eladható kibocsátási egységek felső határa nem haladhatja meg a kibocsátás azon maximum értékét, amelyet egy vállalkozás a kibocsátási sztenderd keretében el tud érni. ${ }^{63}$

A Bizottság eljárása során megjegyezte: azáltal, hogy a hatóságoknak választási lehetőségük volt a kibocsátási engedélyek eladására vagy aukció útján történő értékesítésére, amely egy olyan rendszer felállítására vezetett, ahol az engedélyek az EK Szerződés 87. cikk (1) bekezdése szerinti - most EUMSz 107. cikk (1) bekezdés - állami forrásoknak minősülnek. ${ }^{64}$ Továbbá, mivel a rendszer csak a 250 legnagyobb vállalkozásnak kedvezett - egy olyan körülhatárolható csoportot alkotva, amely a tagállamok közötti kereskedelemben is aktív szerepet játszott - az alkalmassá vált e 250 vállalat helyzetének megerősítésére, hozzájárulva ezzel a piaci viszonyok versenytársak számára történő megváltoztatásához. Annak ellenére, hogy e feltételek teljesülése alapján egyértelműen megállapítható volt az EK Szerződés 87. cikk (1) bekezdése szerinti tiltott állai támogatás megvalósítása, a Bizottság megvizsgálta, hogy a tagállami intézkedés igazolható-e a 87. cikk (3) bekezdés c) pontja alapján.

\footnotetext{
59 A Bizottság N 35/2003. sz. ügyben 2003. június 24-én hozott határozata (Holland $\mathrm{NO}_{\mathbf{x}}$ emisszió-kereskedelmi rendszer), 1.

${ }^{60}$ Hancher - Ottervanger - Slot: 2006, 544.

61 A Bizottság N 35/2003. sz. ügyben 2003. június 24-én hozott határozata (Holland $\mathrm{NO}_{\mathbf{x}}$ emisszió-kereskedelmi rendszer), 2.

62 A Bizottság N 35/2003. sz. ügyben 2003. június 24-én hozott határozata (Holland $\mathrm{NO}_{\mathbf{x}}$ emisszió-kereskedelmi rendszer), 5.

63 A Bizottság N 35/2003. sz. ügyben 2003. június 24-én hozott határozata (Holland $\mathrm{NO}_{\mathbf{x}}$ emisszió-kereskedelmi rendszer), 7.

${ }^{64}$ A Bizottság N 35/2003. sz. ügyben 2003. június 24-én hozott határozata (Holland $\mathrm{NO}_{\mathbf{x}}$ emisszió-kereskedelmi rendszer), 9.
} 
Miután pedig maga a kereskedelmi rendszer - a közösségi szabályok elfogadását megelőző törekvéseként - felállításával jutalmazta azokat a vállalkozásokat, amelyek az alkalmazandó követelmények szintjét meglépve magasabb követelményrendszert vezettek be, ezáltal környezetvédelmi szempontból előnyös helyzetet teremettek. Ezen indokok fényében a Bizottság a tagállami intézkedést a közös piaci szabályokkal összeegyeztethetőnek ítélte, végrehajthatóvá nyilvánítva azt az EK szerződés 87. cikk (1) bekezdésének c) pontja alapján.

A Bizottság határozata a későbbiekben számos kritika tárgyát képezte, mivel az bizonyos körülményeket figyelmen kívül hagyott, így például azt, hogy a nagy ipari létesítményeknek az általános követelményeken felüli további követelményeknek kellett megfelelniük más létesítményekhez képest, valamint, hogy a kibocsátási engedélyek értéke ugyanúgy függött a résztvevő vállalkozásoktól, mint a kormányzat kereskedésre feljogosító engedélyétől. ${ }^{65}$ Továbbá, a Bizottság megközelítését kifogásoló további érvként került megfogalmazásra, hogy addig nem beszélhetünk kibocsátási engedély létezéséről, amíg nincs legalább egy olyan vállalkozás, amely termelési hatékonyságának köszönhetően létrehozza a kibocsátási engedélyeket. ${ }^{66}$

A Bizottság határozatát a holland hatóságok megtámadták az Elsőfokú Bíróság előtt, amely eljárásában arra a következtetésre jutott, hogy az $\mathrm{NO}_{\mathrm{x}}$ kereskedelmi rendszer egy, a vállalkozások számára állami forrásokon keresztül nyújtott előnyt jelentett. Az Elsőfokú Bíróság érvelését azon körülményekre alapozta, hogy a rendszer az általa megszabott követelmények hatálya alá tartozó vállalkozások számára lehetővé tette, hogy a rájuk alkalmazandó felső-határértékig kibocsátási engedélyekkel kereskedjenek egymás között, így az engedélyek forgalomképessége folytán a rendszer piaci értéket ruházott rájuk. ${ }^{67}$ Ezáltal a tagállami intézkedés folytán az engedélyekre ruházott forgalomképesség jelenti a vállalkozások számára nyújtott előnyt. ${ }^{68}$ Továbbá az Elsőfokú Bíróság megvizsgálta a szelektivitás kérdését is, arra a következtésre jutva, hogy a rendszer objektív megfontolásokon alapult és a tagállami intézkedés a legnagyobb szennyezőket célozta az intézkedés környezet védelmének céljával összhangban megfogalmazott objektív kritériumokkal. ${ }^{69}$ Figyelembe véve a rendszer által elérni kívánt célokat és a nagy ipari létesítményekre nehezedő különleges kötelezettségeket, az Elsőfokú Bíróság megállapította, hogy az $\mathrm{NO}_{\mathrm{x}}$ kereskedelmi rendszer felső-határértéke alá tartozó vállalkozások helyzete nem volt összehasonlítható azon vállalkozásokéval, amelyekre e határérték nem volt alkalmazható. ${ }^{70}$

\footnotetext{
65 Piet Jan Slot: $\mathrm{NO}_{\mathrm{x}}$ Emission Trading Rights: A Government Gift or Value Created by Undertakings?, European State Aid Law Quarterly, 2013/12, 62.

${ }^{66}$ Slot 2013, 67.

${ }^{67}$ Az Elsőfokú Bíróság T-233/04. sz. Holland Királyság kontra Európai Közösségek Bizottsága ügyben 2008. április 10-én hozott itélete (EBHT 2008., II-00591.o.) para. 70.

68 Az Elsőfokú Bíróság T-233/04. sz. Holland Királyság kontra Európai Közösségek Bizottsága ügyben 2008. április 10-én hozott ítélete (EBHT 2008., II-00591.o.) para. 74

${ }^{69}$ Az Elsőfokú Bíróság T-233/04. sz. Holland Királyság kontra Európai Közösségek Bizottsága ügyben 2008. április 10-én hozott ítélete (EBHT 2008., II-00591.o.) para. 88.

70 Az Elsőfokú Bíróság T-233/04. sz. Holland Királyság kontra Európai Közösségek Bizottsága ügyben 2008. április 10-én hozott ítélete (EBHT 2008., II-00591.o.) para. 90.
} 
Annak a puszta lehetősége, hogy a kérdéses intézkedés csupán a 250 érintett vállalkozásra korlátozódott nem volt elégséges az intézkedés szelektivitásának megállapításához. ${ }^{71}$ Így a harmadik kritérium teljesülése hiányában az Elsőfokú Bíróság álláspontja szerint az intézkedés nem esett a 87. cikk (1) bekezdésnek tilalma alá.

Az Elsőfokú Bíróság döntését végül a Bíróság bírálta felül. A szelektivitás kérdését tekintve a Bíróság megállapította, hogy a támogatás fogalma „nem foglal magának olyan intézkedéseket, amelyek a vállalkozások eltéró bánásmódját eredményezi olyan terbek tekintetében, abol ezen eltérések a terheket tartalmazó kérdéses rendszer természetéböl erednek. "T2 Amikor a Bíróság arra a kérdésre kereste a választ, hogy vajon Hollandia biztosítani tudja-e az intézkedés 87. cikk (1) bekezdés szerinti szelektívként történő megítélését, arra a következethetésre jutott, hogy sem a jogforrás által létrehozott általános rendszer, sem pedig annak a természete nem volt alkalmas a megkülönböztetés igazolására. ${ }^{73}$

Annak megítélése tekintetében pedig, hogy a holland rendszer egy állami forrásokból származó támogatásnak minősül-e, a Bíróság a következő álláspontra helyezkedett. Mivel a kibocsátási engedélyek forgalomképessége attól függ, hogy az állam jóváhagyja-e az azokkal való kereskedelmet, továbbá hogy az állam lehetôvé teszi-e a többletkibocsátással érintett vállalkozások számára a hiányzó kibocsátási engedély más vállalkozásoktól történő beszerzését, amely végső soron az engedélyek piacának létrehozásához vezet. ${ }^{74}$

\section{Az emisszió kereskedelmi rendszer felülvizsgálata}

A harmadik szakasz tekintetében az EKR jelentős változásokon esett keresztül. A 2009/29/EK irányelv ${ }^{75}$ igyekszik a rendszerben rejlő nagymértékű potenciált kibontakoztatni, részben az első két szakaszban vétett hibákból tanulva. Az irányelv új célkitűzésként az üvegházhatású gázok kibocsátásának 20\%-kal az 1990. évi szint alá történő csökkentésére irányuló kibocsátási szintje alá kell csökkentését határozta meg. ${ }^{76}$ E cél elérése érdekében a kibocsátási egységek mennyiségét éves szinten csökkenteni kell, 1,74\%-nak megfelelően. ${ }^{77}$

\footnotetext{
${ }^{71}$ Az Elsőfokú Bíróság T-233/04. sz. Holland Királyság kontra Európai Közösségek Bizottsága ügyben 2008. április 10-én hozott itélete (EBHT 2008., II-00591.o.) para. 95.

72 A Bíróság C-279/08 P sz. Holland Királyság kontra Európai Bizottság ügyben hozott 2011. szeptember 8-i ítélete (EBHT 2011., ECR I-07671.o.) para.62.

73 A Bíróság C-279/08 P sz. Holland Királyság kontra Európai Bizottság ügyben hozott 2011. szeptember 8-i ítélete (EBHT 2011., ECR I-07671.o.) paras. 76-78.

74 A Bíróság C-279/08 P sz. Holland Királyság kontra Európai Bizottság ügyben hozott 2011. szeptember 8-i ítélete (EBHT 2011., ECR I-07671.o.) para. 88.

75 Az Európai Parlament és a Tanács 2009/29/EK Irányelve (2009. április 23.) a 2003/87/EK irányelvnek az üvegházhatású gázok kibocsátási egységei Közösségen belüli kereskedelmi rendszerének továbbfejlesztése és kiterjesztése tekintetében történő módosításáról

76 2009/29/EK irányelv, 5. preambulumbekezdés

77 2009/29/EK irányelv, 13. preambulumbekezdés
} 
Az új irányelvvel a rendszer az előző irányelv által le nem fedett létesítményekre is kiterjesztette hatályát, szélesebb alkalmazási kört biztosítva az ipari tevékenységek tekintetében. ${ }^{78}$

Az új irányelv már a kibocsátás-áthelyezés problémakörét is figyelembe vette, ${ }^{79}$ amely arra utal, hogy egy adott országban elfogadott kibocsátás-csökkentési törekvések egy másik országban a kibocsátás növekedéséhez vezethetnek, miután a szigorúbb kibocsátási követelményeket alkalmazó államokban székhellyel rendelkező vállalkozások termelési tevékenységüket kiszervezhetik olyan más államokba, ahol a kibocsátáscsökkentési törekvések kevésbé szigorúak, amely egy szektorokra jól lebontható áthelyezési rátát mutat egy 0-tól 100\%-ig terjedő skálán. ${ }^{80}$ E problémakörhöz kapcsolódóan az új irányelv lehetôvé teszi a tagállamok számára, hogy ideiglenes kompenzációt nyújtsanak olyan létesítmények számára, amelyeknél megállapították, hogy jelentôs szénszivárgási kockázatnak vannak kitéve, feltéve hogy az így nyújtott támogatás szükséges és arányos. ${ }^{81}$

Az Irányelv 10. cikke már a kibocsátási egységek aukció útján történő értékesítése irányába mutat elmozdulást a leszármaztatáshoz képest. Továbbá kimondja: a szennyező fizet elvével jobban összeegyeztethető megközelítést kíván biztosítani azáltal, hogy a kibocsátási engedélyek aukciójából származó bevétel 50\%-át környezetvédelmi célok megvalósítására kell fordítani, mint például megújuló energiaforrásokba történő befektetés, erdőirtások megelőzése, valamint a szén-dioxid környezetvédelmi szempontból biztonságos tárolása. ${ }^{82}$

Annak érdekében, hogy 2027-re megtörténjen a kizárólag aukció útján történő értékesítés, szükség van egy átmeneti időszak bevezetésére is. Ezen időszak alatt egy közösségi szintű ex-ante teljesítményértékelés alapú szétosztási rendszer bevezetésére kerül sor, amely az üvegházhatású gázok kibocsátásának csökkentésére irányuló ösztönzőként kíván hatni. ${ }^{83}$ Továbbá 2015 decemberéig 300 millió kibocsátási egység kerül fenntartásra az új belépők számára. ${ }^{84}$

Az új irányelv által bevezetett új elosztási módszer pozitív megítélésben részesült, mivel a kibocsátási egységek elosztása tekintetében - a leszármaztatáshoz képest - a legjobb elérhető piaci alapú eszközhöz folyamodik, ezáltal a legnagyobb fokú környezetvédelmi és allokációs hatékonyság elérésére mellett biztosítja az átláthatóságot és egyszerűséget. ${ }^{85}$

\footnotetext{
78 2009/29/EK irányelv, 10. preambulumbekezdés

79 2009/29/EK irányelv, 26. preambulumbekezdés

${ }^{80}$ OECD 2011, 10.

81 2009/29/EK irányelv, 27. preambulumbekezdés

82 2009/29/EK irányelv, 10. cikk, Vö.: Fodor László: A $\mathrm{CO}_{2}$ leválasztásának és tárolásának (CCS) nemzetközi vetületei, in: Raisz Anikó (szerk.): A nemzetköz̨i környezetjog aktuális kibivásai, Miskolc, Miskolci Egyetem, 2012, 51-61.

83 2009/29/EK irányelv, 10a. cikk, 1. pont (3) bekzedés

84 2009/29/EK irányelv, 10a. cikk 8. pont

85 Guendalina Catti De Gasperi: Making State Aid Control "Greener": The EU Emission Trading System and its Compatibility with Article 107 TFEU, European State Aid Law Quarterly, 2010/9, 797.
} 
A harmadik szakasz további előnye, hogy a közösségi szintű kibocsátási felsőérték meghatározásával és a nemzeti kiosztási tervek eltörlésével, az ipari szereplők oldalán a kiosztási módszerek tekintetében megjelenő bizonytalanság kiiktatásával és egy közös, harmonizált uniós szintű kiosztási módszer bevezetésével biztosíthatóvá vált az átláthatóság. ${ }^{86}$

Ennek ellenére, még a harmadik szakaszban is a kibocsátási egységek összértékének 40\%-a térítésmentesen kerül kiosztásra. ${ }^{87}$ A teljesítményértékelés tekintetében felmerülő legfontosabb kérdés e körben a szelektivitás problémája. A szakirodalomban kiemelésre került, hogy a teljesítményértékelési rendszer igazolhatósága az „objektivitáson, az elfogadott sztenderdek kiterjedtségén valamint a kibocsátáscsökkentési költség struktúrájának homogenitásán” alapszik. ${ }^{88}$ Továbbá a teljesítményértékelésen alapuló rendszerek kevésbé képesek piaci torzulás előidézésére, mivel minden vállalkozással szemben azonos követelményeket támasztanak szektoronként, amely követelmények tükrözik a szektoriális szintû kibocsátás-csökkentési összköltséget. ${ }^{89}$

A kibocsátás áthelyezés problémája azonban továbbra is egy olyan kérdéskör marad, amellyel az Uniónak a jövőben szembe kell néznie, mivel az aukció útján történő értékesítés csak akkor válhat környezetvédelmi szempontból legelőnyösebb megoldássá, hogyha azt világszinten alkalmazzák. ${ }^{90}$ Ilyen helyzetekben azok az államok képeznek veszélyt, ahol nem került nemzeti szinten meghatározásra a kibocsátás mértékének felsô határa - például regionális vagy világszintű együttmúködési keretek között - mivel abban az esetben, hogyha ez a felsőérték kellőképp alacsonyan került meghatározásra, a vállalkozások nem fogják termelésüket abba az országba áthelyezni. ${ }^{91}$ E probléma még a felső értékhatár egyoldalú meghatározása vagy egyoldalú szigorítása során is felmerülhet, amely azonban határon átnyúló kiigazítással megelőzhetővé válik. ${ }^{92}$ A kibocsátás áthelyezés szempontjából magas kockázatú ipari szektorok tekintetében a döntéshozók átmeneti támogatást is nyüjthatnak, ,a kibocsátás tekintetében intenzín kereskedelemnek kitett iparágak” számára, ${ }^{93}$ amely ilyen értelemben állami támogatás nyújtásának is megfeleltethetővé válik.

\footnotetext{
${ }^{86}$ Európai Bizottság: European Emission Trading Scheme Handbook, 44.

87 Dirk Böhler: The EU Emission Trading Scheme - Fixing a Broken Promise; Environmental Law Review, 2013/15, 97.

${ }^{88}$ De Gasperi 2010, 803.

89 De Gasperi 2010, 804.

90 De Gasperi 2010, 799.

91 OECD 2011, 174.

92 OECD 2011, 10-11.

93 OECD 2011, 123.
} 
Az azonban továbbra is kérdéses marad, hogy a kibocsátás-áthelyezés kockázatával érintett szektorokban a kibocsátási egységek leszármaztatás útján történő elidegenítése mennyiben fog egy fenntartható megoldásnak bizonyulni. Így tehát a kibocsátás-áthelyezés tekintetében két nagy érdek kerül ütköztetésre: egyrészt érdemesebb-e állami támogatást nyújtani az EU-n belüli a vállalkozások számára a támogatások fokozatos csökkentése és a kibocsátási követelmények szigorítása mellett, vagy pedig másrészt a szennyező fizet elvének kell érvényt szerezni, amely a különböző ipari szektorok tekintetében nagymértékű kibocsátás áthelyezéshez vezethet.

\section{Konklúzió}

Összegezve a fentebb részletezett problémákat, könnyen lehet arra a következtetésre jutni, hogy az Európai Emisszió-kereskedelmi rendszer - az állami támogatások tilalmának környezetvédelmi megfontolásokból történő alkalmazása és a szennyező fizet elve összeegyeztethetőségének alapvető nehézségeit tekintve ellentmondásokkal telt felépítése számos kérdés tekintetben hagy kétséget maga után. Már önmagában is egyértelmű, hogy az állami támogatások mögött húzódó megfontolások nem hozhatók teljes mértékben összhangba a szennyező fizet elvével.

Az e tekintetben felmerülő első kérdés, hogy az uniós emisszió-kereskedelmi rendszerben a szennyező kinek fizet? Miután az érintett vállalkozások számára ingyenesen kerültek a kibocsátási egységek elosztásra, ezért azokat környezetvédelmi megfontolások figyelembe vétele nélkül tudták szabadon tőkésíteni. A kibocsátási egységek piacon történő értékesítése folytán azok inkább a szennyező fizet egy másik szennyezőnek megközelítést tükröztek, mintsem a szennyező fizet el érvényesülésének biztosítását, amely önmagában véve a rendszer környezeti alapelvekkel való összeegyeztethetőségét kérdőjelezi meg, miután a tőkésítésből származó bevételt a vállalkozások nem szükségszerűen környezetvédelmi beruházásokba fektették.

A rendszer legérdekesebb jellemzője, hogy azzal kapcsolatban könnyen arra a következtetésre is lehet jutni, hogy a kibocsátási egységek leszármaztatás útján történő átruházása nem tekinthető egy állami intézkedésnek, mivel e módszert maga az irányelv szabályozza. Így egy logikus érvként fogalmazódhat meg, hogy az uniós jog alatt végrehajtott intézkedések nem minősülnek állami támogatásnak. Természeten az irányelv átültetésére nemzeti szinten kellett sort keríteni, azonban további kérdésként fennmarad a nemzeti kiosztási tervek irányelv tekintetében történő minősítése. Mivel a nemzeti kiosztási terveket a tagállamok a Bizottság ellenőrzése mellett diszkrecionális jogkörükben határozták meg, ezért nehéz arra a következtetésre jutni, hogy a kibocsátási egységek leszármaztatása ne lenne az államnak betudható. Amint az bemutatásra került, az irányelv elfogadása előtt a Bizottság környezetvédelmi célokra hivatkozva az EUMSz 107. cikk (3) bekezdésének c) pontja alapján hagyta jóvá az üvegházhatású gázok kibocsátásának szabályozását. Az irányelv elfogadását követően azonban élet váltás következett be a Bizottság hozzáállásában. 
Ez a hirtelen váltás annak tudható be, hogy amíg a kibocsátási engedélyek ellenérték nélkül történő átadását az uniós szinten történő szabályozása igazolja, addig az 5 és 10\%-os aukcióra bocsátandó részek vonatkozásában a Bizottság több esetben is az állami támogatások tilalmára vonatkozó szabályokkal összeegyeztethetetlennek minősített egyes nemzeti kiosztási terveket.

Továbbá e tekintetben az is megkérdőjelezhető, hogy mennyiben és milyen mértékben teljesül az EUMSz 11. cikkében kimondott, a környezetvédelmi érdekek más uniós politikákba történő beépítésének követelményének figyelembe vétele. E klauzula azt a problémakört veti fel, hogy a környezetvédelmi vonatkozású állam támogatások összeegyeztethetőek-e a környezetvédelmi érdekek uniós politikákba történő integrációjának lehetőségével. Abban az esetben, hogyha a környezetjogi alapelvek uniós szinten szigorú betartására kerülne sor, akkor az ilyen értelemben a támogatások nyújtását is kizárhatná az érintett vállalkozások számára. Az Európai Kibocsátás-kereskedelmi Rendszerrel összefüggésbe hoztató állami támogatásokra vonatkozó megközelítés egy egyértelmű jele az említett 11. cikk érvényesülésének. E megközelítést a Bizottság határozatai is alátámasztják, miután az EKR létrehozása előtt, az üvegházhatású gázok kibocsátásához kapcsolódó bármilyen állami támogatást a Bizottság a belső piaccal összeegyeztethetőnek minősített. Az EKR irányelv hatályba lépést követően, a térítés nélkül történő kiosztás következtében a szennyező fizet elve egyértelmúen meggyengült, magában hordozva az ipari szektorokban fennálló verseny torzulását. Mindez azt is mutatja, hogy a környezetvédelmi megfontolások térnyerése ellenére nem képesek a versenyjoggal szemben érvényesülni, ami által a környezetvédelmi elvek és az EUMSz 11. cikkében kimondott integritás klauzula is csak korlátolt jelentőséggel bír. 